OLIVIER J. BLANCHARD

Massachusetts Institute of Technology

\author{
LAWRENCE H. SUMMERS
}

Harvard University

\title{
Perspectives on High World Real Interest Rates
}

REAL INTEREST RATES in the United States have reached extremely high levels in the last several years. This surge in real rates at all maturities has not lacked explanations. Large current and prospective deficits, tight money, better profit prospects, financial deregulation, and increased uncertainty are among the factors that have been blamed for high real rates. If one looks only at the performance of the U.S. bond market, it is difficult to discriminate among possible explanations for the behavior of real interest rates. This paper examines the worldwide behavior of interest rates and the performance of other asset markets besides the U.S. bond market in order to better explain high real rates.

Even a cursory inspection of the data makes it clear that high real rates are a worldwide phenomenon. In nearly all the major countries of the Organization for Economic Cooperation and Development (OECD), real interest rates on both short- and long-term bonds have risen dramatically. This is not surprising. Interest rates today are substantially determined worldwide, rather than domestically, because a large pool of capital flows toward nations with high real rates, tending to equalize rates around the world. Thus, it is appropriate to relate national interest

We have benefited from many discussions and comments from colleagues and members of the Brookings Panel. We also want to thank John Campbell, Bernard Connolly, Pentti Kouri, P. A. Muet, Robert Price, and Jean de Rosen for comments. We thank Sara Johnson of Data Resources, Inc., for making available to us past DRI forecasts; we also thank DRI for access to its data base and for computer time. Michael Burda and James Kahn provided valuable research assistance. 
rates to international events, a connection that has long been recognized by economists living in small, open economies. But most discussions of U.S. interest rates entirely ignore international developments. Given that high real rates are a worldwide phenomenon, we seek an account that can explain high real rates in all countries rather than only in the United States.

A surprising feature of the recent period of high real rates has been the relatively strong performance of stock markets around the world. One would expect that a sharp increase in real interest rates at long maturities, caused by fiscal and monetary policies, would depress stock prices significantly. Yet in all major countries, real stock prices have been surprisingly strong. Dividend-price ratios have in no way followed real rates on long-term bonds. Clearly a full understanding of recent events requires some explanation of the behavior of stock prices, and we try to account below for the behavior of both bond and stock prices.

We begin by reviewing the behavior of real interest rates and asset prices over the last several years. Measuring real interest rates precisely is not possible, because they depend on the level of expected inflation, which is not observable. We use alternative approaches to describing the term structure of real rates for a number of countries. The results indicate that real rates are expected to remain high for some time to come. There is some evidence suggesting that real rates are expected to return eventually toward lower levels. We consider the performance of stock markets in the United States and abroad and document their surprising strength in the face of high real rates.

In the second section of the paper, we discuss theoretically the determination of real interest rates, stock prices, and exchange rates in the short and long run. Four possible causes of increases in real interest rates are examined: reductions in saving, increases in profitability, contractionary monetary policies, and portfolio shifts. In each case we characterize the effects of the change on the different asset markets. It is apparent from our discussion that ascribing high real interest rates to only one cause will not fit the facts. The pattern of asset price movements that has been observed in recent years does not correspond to the predicted effects of any single type of shock. The next four sections of the paper then examine in turn the empirical importance of each type of shock in explaining recent developments. 
Since deficits are probably the most commonly adduced explanation for high worldwide real rates, we start with an analysis of fiscal policy in the major nations of the OECD. The much-ballyhooed fiscal expansion has indeed taken place in the United States, but it has been offset to a significant extent by contractions in other nations. The total inflationadjusted structural deficit for the major nations of the OECD has not changed significantly between 1978 and 1984. It seems quite unlikely that the direct effects of fiscal expansion can account for the dramatic increases in real rates that have been observed. We briefly examine other possible causes of a worldwide decline in saving but find little to explain the behavior of real interest rates.

The second hypothesis is that rates have increased because of a rise in the current or prospective demand for investment funds. If correct, this hypothesis has the virtue of explaining why stock prices have risen as well as why interest rates have increased. In addition to the recovery, the demand for investment funds may have risen because of the business tax cuts enacted in the United States and the reductions in uncertainty associated with an increase in the "inflation consciousness" of governments around the world. We explore these hypotheses by examining the recent performance of investment. Overall, the evidence supports the hypothesis that expected profitability has increased by more than might be expected from cyclical factors.

The third possible cause, tight money, may well be a major culprit in explaining high long-term real rates. A great deal of evidence confirms that monetary policies were extremely tight during the 1978-82 period, and there are substantial reasons to believe that monetary policies can affect even long real rates. Thus it seems natural to blame much of the initial increase in real rates on tight money. However, the current level of rates is less easy to link to tight money. Tight money cannot be the only culprit. We examine whether the mix of fiscal and monetary policies can explain high rates. We find some plausibility to an explanation based on "loose U.S. fiscal policy, tight European money" or "loose U.S. fiscal policy, tight anticipated world money."

Concerning the last potential cause, the effects of portfolio shifts that stem from changes in asset supplies or risk characteristics, we find little reason to believe that such shifts are responsible for the high level of real rates. We conclude the paper by assessing the implications of our analysis 
for the problems of forecasting future developments and making future policy.

\section{Asset Prices and Asset Returns}

Because one needs evidence on a variety of assets in different countries to assess explanations of current high rates in the United States, this section examines the behavior of asset prices and returns in six major OECD countries-the United States, France, West Germany, the United Kingdom, Italy, and Japan, which accounted for 89 percent of total OECD gross national product in 1983. We first present time series for short and medium-term real rates and then examine the behavior of stock prices and the required return on equity.

\section{REAL INTEREST RATES}

We present estimates of real short rates in tables 1 and 2 . The nominal rates for the period 1978-84 are three-month Eurorates for five of the six countries; for Italy we use a domestic rate rather than the unreliable Eurolira rate. Nominal rates for the period $1965-77$ are domestic short rates. In table 1 we construct real rates for $1965-84$ by creating statistical forecasts of inflation based on forecasts from an estimated autoregressive process of inflation. Because we suspect that the inflation process and, therefore, the autoregressive representation of inflation have probably changed over time, we use rolling autoregressive forecasts, reestimating the process each period on the basis of the last twenty-four quarters. Even so, our forecasts of inflation from 1982 onward usually exceed other official or commercial forecasts, which suggests that the decline in expected inflation was more rapid than can be captured by our statistical method. In table 2 we construct real rates for the first quarter of each year from 1978 to 1984 by using the previous December's DRI (Data Resources, Inc.) forecast of inflation and, for 1984:2, their April forecast. The real rates so constructed are in general higher for the latter part of the sample period because the expected rate of inflation is lower. Before discussing them, we turn to the construction of medium-term real rates and rates of return on equity.

We present estimates of medium-term real rates in tables 3 and 4 . The 
Table 1. Real Short-Term Interest Rates Using Statistical Forecasts of Inflation, 1965-84:2

Percent

\begin{tabular}{lcrcrrr}
\hline Period & $\begin{array}{c}\text { United } \\
\text { States }\end{array}$ & France & $\begin{array}{c}\text { West } \\
\text { Germany }\end{array}$ & $\begin{array}{c}\text { United } \\
\text { Kingdom }\end{array}$ & Italy & Japan \\
\hline $1965-72$ & 1.5 & 1.7 & 3.0 & 1.5 & n.a. & 1.0 \\
$1973-77$ & 1.5 & -0.3 & 1.4 & -3.9 & -2.5 & -3.3 \\
1978 & 0.3 & 0.7 & 0.8 & -0.9 & -2.5 & -5.0 \\
1979 & 1.3 & -0.7 & 1.2 & -4.3 & -4.4 & 0.4 \\
1980 & 0.4 & 0.3 & 3.2 & 0.9 & 0.0 & 3.4 \\
1981 & 7.0 & 3.6 & 6.0 & 1.1 & 2.0 & 1.7 \\
1982 & 6.5 & 4.9 & 3.8 & 1.5 & 2.8 & 2.7 \\
1983 & 4.7 & 4.5 & 1.4 & 2.3 & 3.2 & 2.9 \\
$1984: 1$ & 4.6 & 4.0 & 2.6 & 1.4 & 3.4 & 4.6 \\
$1984: 2$ & 5.4 & 1.5 & 3.0 & 1.7 & n.a. & 6.1 \\
\hline
\end{tabular}

Source: Nominal interest rates for 1965-77, International Monetary Fund, International Financial Statistics, vol. 34 (October 1984) and previous issues, line 60c for the United States and the United Kingdom; line 60b for the others; for 1978-84, Data Resources, Inc. Inflation series, constructed as explained in the text, based on IMF, International Financial Statistics, line 64.

n.a. Not available.

a. Nominal interest rates for 1965-77 are the Treasury bill rate for the United States and the United Kingdom and the call money rates for the others; for 1978-84, a domestic rate for Italy and the three-month Eurocurrency rates for the others. Inflation is the expected rate of change of the CPI from the first month of the quarter to the first month of the next quarter based on forecasts from an estimated autoregressive process. Annual values are averages of quarterly data.

nominal rates with which we start are yields to maturity on public bonds of five- to seven-year maturities for most countries. We then construct real rates by defining

$$
R_{t}^{k} \equiv I_{t}^{k}-\frac{(1-g)}{\left(1-g^{k}\right)} \sum_{i=0}^{k-1} g^{i} \pi_{t, t+i} \quad g=(1+\bar{I})^{-1} .
$$

The variables $R_{t}^{k}$ and $I_{t}^{k}$ are the real and nominal rates on a bond of maturity $k$, and $\pi_{t, t+i}$ is the forecast of inflation in period $t+i$, as of time $t$. The variable $\bar{I}$ is the mean nominal rate over the period we examine. Thus the real rate so defined is equal to the nominal rate minus a weighted average of expected inflation over the life of the bond. In table 3, we report real rates constructed using statistical forecasts obtained with the same method used in table 1 . In this case, however, we use the estimated autoregressive process to generate inflation forecasts over the life of the bond, not just one period ahead. The rates in table 4 are constructed using DRI forecasts of inflation.

Constructing long real rates would require constructing expected inflation or using commercial forecasts of inflation over the next ten to 
Table 2. Short-Term Nominal and Real Interest Rates Using DRI Forecasts of Inflation, 1978:1-84:2

Percent

\begin{tabular}{|c|c|c|c|c|c|c|}
\hline Period and measure & $\begin{array}{l}\text { United } \\
\text { States }\end{array}$ & France & $\begin{array}{c}\text { West } \\
\text { Germany }\end{array}$ & $\begin{array}{c}\text { United } \\
\text { Kingdom }\end{array}$ & Italy & Japan \\
\hline \multicolumn{7}{|l|}{$1978: 1$} \\
\hline Nominal interest rate & 6.5 & 8.9 & 3.6 & 5.8 & 11.1 & 4.8 \\
\hline Inflation rate & 6.2 & 10.1 & 4.5 & 10.5 & 10.1 & 6.9 \\
\hline Real interest rate & 0.3 & -1.2 & -0.9 & -4.7 & 1.0 & -2.1 \\
\hline \multicolumn{7}{|l|}{ 1979:1 } \\
\hline Nominal interest rate & 9.4 & 6.6 & 3.9 & 11.9 & 11.3 & 4.3 \\
\hline Inflation rate & 8.8 & 12.5 & 2.6 & 12.7 & 13.5 & 4.5 \\
\hline Real interest rate & 0.6 & -5.9 & 1.3 & -0.8 & -2.2 & -0.2 \\
\hline \multicolumn{7}{|l|}{ 1980:1 } \\
\hline Nominal interest rate & 12.0 & 12.0 & 8.9 & 15.8 & 16.4 & 8.1 \\
\hline Inflation rate & 12.0 & 12.0 & 6.2 & 14.8 & 16.1 & 7.7 \\
\hline Real interest rate & 0.0 & 0.0 & 2.7 & 1.0 & 0.3 & 0.4 \\
\hline \multicolumn{7}{|l|}{ 1981:1 } \\
\hline Nominal interest rate & 14.7 & 10.7 & 9.5 & 12.9 & 17.6 & 8.9 \\
\hline Inflation rate & 13.9 & 12.2 & 3.5 & 9.0 & 18.5 & 6.2 \\
\hline Real interest rate & 0.8 & -1.5 & 6.0 & 3.9 & -0.9 & 2.7 \\
\hline \multicolumn{7}{|l|}{$1982: 1$} \\
\hline Nominal interest rate & 12.4 & 15.2 & 10.5 & 14.1 & 20.9 & 6.6 \\
\hline Inflation rate & 6.6 & 13.7 & 3.7 & 9.9 & 15.4 & 3.9 \\
\hline Real interest rate & 5.8 & 1.5 & 6.8 & 4.2 & 5.5 & 2.7 \\
\hline \multicolumn{7}{|l|}{ 1983:1 } \\
\hline Nominal interest rate & 7.8 & 12.7 & 5.8 & 10.6 & 19.3 & 6.6 \\
\hline Inflation rate & 4.9 & 12.3 & 1.2 & 5.2 & 12.9 & 2.7 \\
\hline Real interest rate & 2.9 & 0.4 & 4.6 & 5.4 & 6.4 & 3.9 \\
\hline \multicolumn{7}{|l|}{ 1984:1 } \\
\hline Nominal interest rate & 8.9 & 12.4 & 6.1 & 8.9 & 18.1 & 6.1 \\
\hline Inflation rate & 3.7 & 7.5 & 1.2 & 5.4 & 14.5 & 1.0 \\
\hline Real interest rate & 5.2 & 4.9 & 4.9 & 3.5 & 3.6 & 5.1 \\
\hline \multicolumn{7}{|l|}{$1984: 2$} \\
\hline Nominal interest rate & 9.7 & 12.2 & 5.8 & 8.4 & 17.7 & 5.9 \\
\hline Inflation rate & 5.1 & 6.8 & 2.0 & 7.4 & 12.5 & 1.8 \\
\hline Real interest rate & 4.6 & 5.4 & 3.8 & 1.0 & 5.2 & 4.1 \\
\hline
\end{tabular}

Source: Nominal interest rates, same as table 1 ; inflation forecasts, DRI.

a. Inflation rate is the December forecast of CPI inflation for the following quarter, with the exception of 1984:2, for which the April forecast was used.

twenty years. We thought it would be unwise to attempt such construction; but we shall examine evidence on long rates in a less formal way below.

The clear conclusion is that of a large increase in real rates on bonds in all countries. Tables 1 and 3, constructed using statistical forecasts, imply that the average short real rate increased by 460 basis points between 1978 and 1984:2 and that the average medium-term real rate 
Table 3. Medium-Term Real Interest Rates Using Statistical Forecasts of Inflation, 1965-84:2a

Percent

\begin{tabular}{lrccccc}
\hline Period & $\begin{array}{c}\text { United } \\
\text { States }\end{array}$ & France & $\begin{array}{c}\text { West } \\
\text { Germany }\end{array}$ & $\begin{array}{c}\text { United } \\
\text { Kingdom }\end{array}$ & Italy & Japan \\
\hline $1965-72$ & 1.4 & 3.1 & 4.0 & 2.2 & 3.3 & 1.3 \\
$1973-77$ & -0.9 & n.a. $^{\mathrm{b}}$ & 1.3 & n.a. $^{\mathrm{b}}$ & n.a. $^{\mathrm{b}}$ & n.a. $^{\mathrm{b}}$ \\
1978 & 0.2 & 0.4 & 3.2 & -3.0 & -1.4 & -4.8 \\
1979 & 0.0 & -0.2 & 3.9 & -3.3 & -2.1 & -1.2 \\
1980 & -0.2 & 2.5 & 3.9 & -1.8 & -0.1 & 2.6 \\
1981 & 4.2 & 2.0 & 5.4 & 0.3 & 3.1 & 2.9 \\
1982 & 4.5 & 2.9 & 4.1 & 0.6 & 3.7 & 3.5 \\
1983 & 5.4 & 3.0 & 3.4 & 1.0 & 2.2 & 3.7 \\
$1984: 1$ & 4.6 & 2.7 & 3.6 & 1.5 & 1.3 & 3.5 \\
$1984: 2$ & 6.1 & 2.2 & 1.2 & 3.4 & 0.3 & 4.2 \\
\hline
\end{tabular}

Source: Nominal interest rates for France, West Germany, the United Kingdom, and the United States, Organization for Economic Cooperation and Development, OECD Financial Statistics, line II2b1; for Italy, line II2b2; for Japan, IMF, International Financial Statistics, line 61. Inflation rate, constructed as explained in the text, from IMF, International Financial Statistics, line 64.

n.a. Not available.

a. Nominal interest rates are as follows: United States and United Kingdom, government bonds, secondary market, five-year maturity; France, bond yield, secondary market, ten-or-more-years maturity; West Germany, public bonds, secondary market, three-to-seven-year maturity; Italy, "crediop" bonds, five-year average maturity; Japan, government bond yield, secondary market, seven-year maturity. Expected inflation was constructed as in table 1, but the forecasts were made over the entire life of the bond, assuming maturities of twenty quarters for the United States, West Germany, the United Kingdom, and Italy, twenty-eight quarters for Japan, and forty quarters for France. Annual values are averages of quarterly data.

b. Expected inflation could not be computed because the estimated autoregressions were unstable for part of the period.

rose by 380 points in the same period. Tables 2 and 4 , constructed using DRI forecasts, imply an average increase of 520 basis points in short rates and an average increase of 270 points in the medium-term rate (which excludes Japan). However, these averages hide important differences both across periods and across countries.

Two distinct periods emerge from the tables. The first, from 1978 to 1982 , is one of sharp increases in real rates. From tables 2 and 4 one derives for this first period an average increase of 560 basis points for short rates and 360 points for medium-term rates. The second period, from 1982 on, is one of high but slightly declining rates. The data in tables 2 and 4 for this second period indicate an average decrease of 40 basis points for short rates and 90 points for medium-term rates.

There is also a clear difference between the experiences of the United States and of Europe. The increase in U.S. rates is much more pronounced than the increase in European rates. Table 4 shows that the U.S. increase is 490 basis points for medium-term rates from 1978 to 1984:2, compared with 215 points for the average European increase. 
Table 4. Medium-Term Nominal and Real Interest Rates Using DRI Forecasts of Inflation, 1978:1-84:2a .

Percent

\begin{tabular}{|c|c|c|c|c|c|}
\hline Period and measure & $\begin{array}{l}\text { United } \\
\text { States }\end{array}$ & France & $\begin{array}{c}\text { West } \\
\text { Germany }\end{array}$ & $\begin{array}{c}\text { United } \\
\text { Kingdom }\end{array}$ & Italy \\
\hline \multicolumn{6}{|l|}{ 1978:1 } \\
\hline Nominal interest rate & 7.7 & 11.2 & 5.4 & 9.5 & 14.1 \\
\hline Inflation rate & 5.5 & 8.8 & 4.0 & 9.4 & 9.6 \\
\hline Real interest rate & 2.2 & 2.4 & 1.4 & 0.1 & 4.5 \\
\hline \multicolumn{6}{|l|}{ 1979:1 } \\
\hline Nominal interest rate & 9.4 & 9.7 & 6.2 & 13.5 & 13.7 \\
\hline Inflation rate & 7.3 & 9.8 & 3.8 & 9.0 & 12.6 \\
\hline Real interest rate & 2.1 & -0.1 & 2.4 & 4.5 & 1.1 \\
\hline \multicolumn{6}{|l|}{$1980: 1$} \\
\hline Nominal interest rate & 10.8 & 12.5 & 3.1 & 14.9 & 14.8 \\
\hline Inflation rate & 9.8 & 9.3 & 4.8 & 10.8 & 12.9 \\
\hline Real interest rate & 1.0 & 3.2 & 3.3 & 4.1 & 1.9 \\
\hline \multicolumn{6}{|l|}{$1981: 1$} \\
\hline Nominal interest rate & 12.8 & 14.6 & 9.1 & 13.3 & 17.0 \\
\hline Inflation rate & 10.6 & 10.7 & 4.2 & 11.2 & 15.2 \\
\hline Real interest rate & 2.2 & 3.9 & 4.9 & 2.1 & 1.8 \\
\hline \multicolumn{6}{|l|}{$1982: 1$} \\
\hline Nominal interest rate & 14.6 & 16.4 & 9.9 & 16.4 & 21.0 \\
\hline Inflation rate & 7.7 & 13.1 & 4.2 & 11.1 & 13.6 \\
\hline Real interest rate & 6.9 & 3.3 & 5.7 & 5.3 & 7.4 \\
\hline \multicolumn{6}{|l|}{$1983: 1$} \\
\hline Nominal interest rate & 10.0 & 15.0 & 7.5 & 11.4 & 19.9 \\
\hline Inflation rate & 5.7 & 8.7 & 3.5 & 9.1 & 14.8 \\
\hline Real interest rate & 4.3 & 6.3 & 4.0 & 2.3 & 5.1 \\
\hline \multicolumn{6}{|l|}{$1984: 1$} \\
\hline Nominal interest rate & 11.4 & 13.8 & 8.1 & 10.7 & 16.6 \\
\hline Inflation rate & 4.9 & 8.7 & 4.2 & 7.4 & 12.8 \\
\hline Real interest rate & 6.5 & 5.1 & 3.9 & 3.3 & 3.8 \\
\hline \multicolumn{6}{|l|}{$1984: 2$} \\
\hline Nominal interest rate & 12.4 & 13.8 & 7.7 & 10.5 & 15.4 \\
\hline Inflation rate & 5.3 & 8.0 & 4.4 & 6.2 & 11.8 \\
\hline Real interest rate & 7.1 & 5.8 & 3.3 & 4.3 & 3.6 \\
\hline
\end{tabular}

Source: Nominal interest rates, same as table 3; inflation forecasts, DRI.

a. Inflation rate is the forecast as of the month preceding the quarter. Forecast of inflation for Japan was not available.

Table 3 shows U.S. rates in 1981-84 to be high compared with their average value during either $1965-72$ or 1973-77, while European rates are not far from their 1965-72 values. Indeed, one of the surprising results of table 3 is the relative constancy of the German medium-term 
real rate throughout the $1965-84$ period. We have excluded Japan from this comparison; medium-term rates there are high compared with 196572; the earlier period is, however, one of tight financial control, and interest rates during that period imperfectly reflect market forces.

There are two major characteristics of current interest rates. The first is that U.S. real rates are now higher than elsewhere. Tables 2 and 4 show that real short rates are at 4.6 percent for the United States versus 3.8 percent for Europe and 4.1 percent for Japan; real long rates are at 7.1 percent for the United States versus 4.2 percent for Europe.

The second characteristic is that medium-term real rates are at least as high as short rates. Can we say anything about long real rates? There is fortunately some market information that obviates the need for longrun inflation forecasts. Since 1981, indexed bonds have been issued by the British government, and the market for them has been open to the public since 1982. Table 5, which gives some information on the yield curve of these bonds for various dates and various maturities, suggests two conclusions. The first conclusion, which confirms the earlier tables, is that real interest rates have risen significantly in Britain between 1982 and the present at all maturities. However, the second conclusion is that long rates have increased by less than short or medium-term rates. Computing implicit forward rates as of June 1984, we get a current fouryear rate of 5.13 percent, an implicit eight-year rate in 1988 of 3.58 percent, and an implicit ten-year rate in 1996 of 3.00 percent. To the extent that this indexed bond market is not too idiosyncratic, this evidence is consistent with the view that real rates are eventually expected to decline. ${ }^{1}$

\section{STOCK PRICES AND EQUITY RETURNS}

Figure 1 shows $1970-84$ real stock prices, and table 6 shows $1965-84$ dividend-price ratios. Dividend-price ratios are only crude measures of expected rates of return on equities, because they do not take into

1. Although indexed bonds do not yet exist in the United States on a large scale, First City National Bank of Houston introduced in October 1984 a thirty-year indexed certificate of deposit. It pays 4 percent, thus suggesting high long real rates in the United States as well. The current term structure of nominal rates in the United States is approximately flat for maturities equal to or longer than five years, a characteristic shared by term structures at the same stage of the four previous recoveries. Whether real long rates are higher or lower than real medium-term rates therefore depends on whether inflation is expected to decrease or increase after 1989. 
Table 5. Real Yields on British Indexed Bonds, 1981-84

Percent

\begin{tabular}{lllll}
\hline & \multicolumn{4}{c}{ Year of maturity } \\
\cline { 2 - 5 } Period & 1988 & 1996 & 2006 & 2011 \\
\hline 1981 & & & & \\
June & $\ldots$ & 2.37 & $\ldots$ & $\ldots$ \\
September & $\ldots$ & 3.13 & 2.90 & $\ldots$ \\
December & $\ldots$ & 3.17 & 2.92 & $\ldots$ \\
1982 & & & & \\
March & 2.69 & 2.86 & 2.71 & 2.70 \\
June & 2.96 & 3.14 & 2.95 & 2.93 \\
September & 3.48 & 3.18 & 2.95 & 2.90 \\
December & 2.52 & 2.90 & 2.72 & 2.71 \\
1983 & & & & \\
March & 3.01 & 2.79 & 2.61 & 2.60 \\
June & 4.18 & 3.46 & 3.04 & 2.97 \\
September & 3.41 & 3.40 & 3.15 & 3.04 \\
December & 3.73 & 3.54 & 3.14 & 3.09 \\
1984 & & & & \\
March & 4.62 & 3.78 & 3.33 & 3.25 \\
June & 5.13 & 4.10 & 3.60 & 3.52 \\
\hline
\end{tabular}

Source: W. Greenwell and Company, "British Funds," in Z. Bodie and James Poterba, "The British Indexed Bond Market."

account either cyclical movements or trend growth in dividends. This leads us to go one step further. We define the real required rate of return on equity in period $t, E_{t}$, implicitly by the relation

$$
P_{t}=\sum_{i=0}^{\infty}\left(1+E_{t}\right)^{-i} D_{t, t+i}
$$

where $P_{t}$ is the real stock price and $D_{t, t+i}$ is the real dividend expected at time $t$ in period $t+i$. The variable $E_{t}$ may be interpreted as an internal rate of return. If dividends are expected to grow for cyclical or trend reasons, $E_{t}$ will be higher than the current dividend-price ratios. The rate $E_{t}$ can be thought of as a "cyclically adjusted dividend-price ratio." Computing $E_{t}$ requires forecasting the sequence of expected dividends at time $t$. We do this by estimating rolling bivariate autoregressions for $P$ and $D$ for each $t$ for the last twenty-four quarters and generating for each $t$ forecasts of expected dividends. We use a bivariate rather than a univariate autoregression, as we did in projecting inflation above, to 
Figure 1. Real Stock Prices, 1970-84
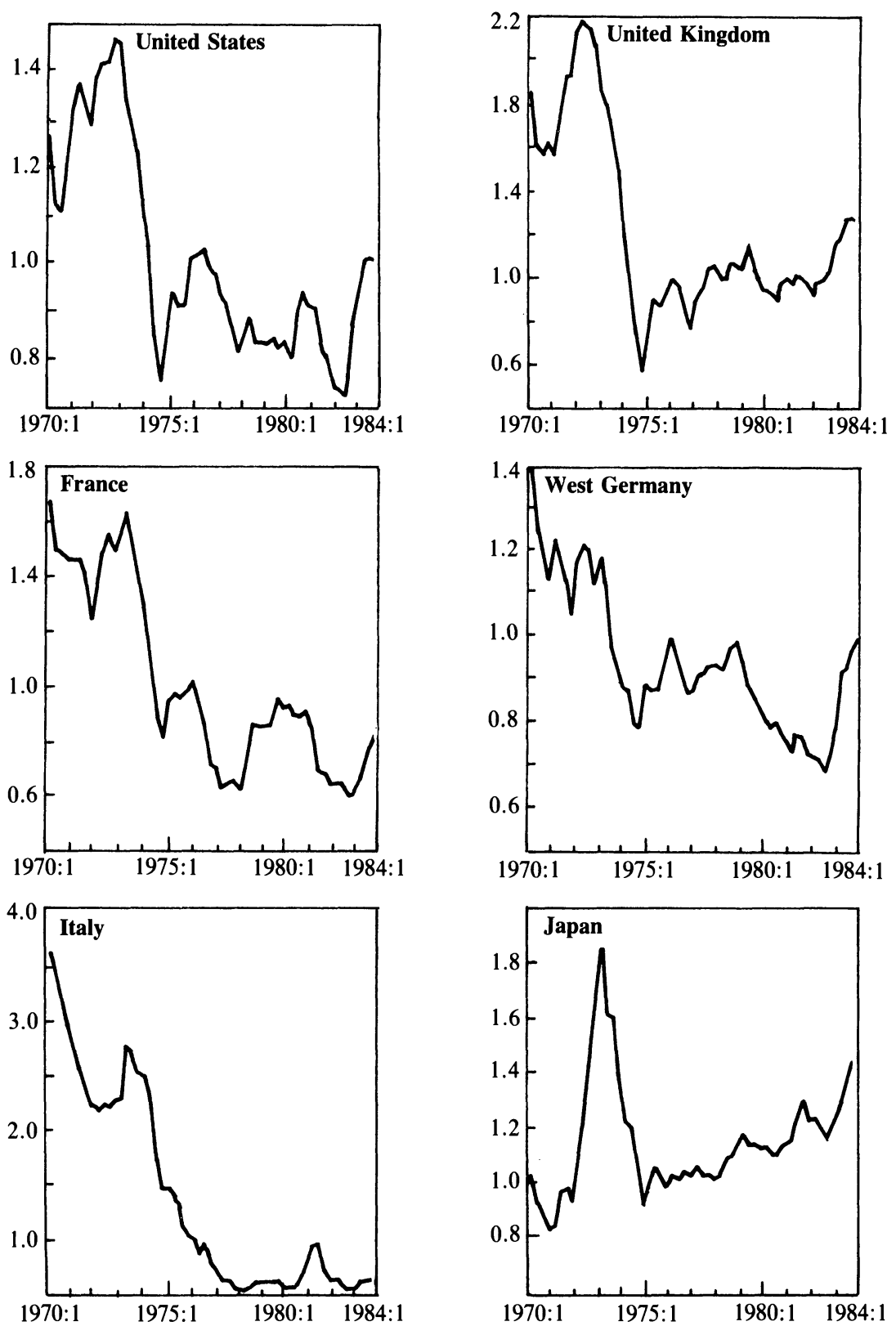

Source: Organization for Economic Cooperation and Development, OECD Financial Statistics, various issues. Data for West Germany extend to 1984:1; for others, 1983:4.

a. Index, 1976:1 = 1.0. Deflators are the domestic CPI. 
Table 6. Dividend-Price Ratios, 1965-84:2a

Percent

\begin{tabular}{lcccccc}
\hline Period & $\begin{array}{c}\text { United } \\
\text { States }\end{array}$ & France & $\begin{array}{c}\text { West } \\
\text { Germany }\end{array}$ & $\begin{array}{c}\text { United } \\
\text { Kingdom }\end{array}$ & Italy & Japan \\
\hline $1965-72$ & 3.2 & $3.8^{\mathrm{b}}$ & 3.6 & 4.5 & 4.1 & n.a. \\
$1973-77$ & 4.0 & 6.2 & 3.6 & 5.9 & 3.9 & 2.0 \\
1978 & 5.3 & 6.6 & 4.5 & 5.5 & 5.1 & 1.6 \\
1979 & 5.5 & 5.7 & 5.0 & 5.7 & 3.4 & 1.4 \\
1980 & 5.2 & 6.2 & 5.7 & 6.7 & 2.5 & 1.5 \\
1981 & 5.2 & 8.1 & 5.7 & 6.1 & 2.0 & 1.4 \\
1982 & 5.8 & 7.9 & 5.5 & 5.6 & 2.2 & 1.6 \\
1983 & 4.4 & 6.6 & 3.9 & 4.7 & 2.4 & 1.3 \\
$1984: 1$ & 4.5 & 5.1 & 3.2 & 4.3 & 2.6 & 1.1 \\
$1984: 2$ & 4.7 & 5.0 & n.a. & 4.0 & 2.4 & 1.0 \\
\hline
\end{tabular}

Source: $O E C D$ Financial Statistics.

n.a. Not available.

a. Values for 1984:1 and 1984:2 are for the first month of the quarter.

b. Adjusted for income tax credit.

allow for the possibility that stock prices contain information not contained in current and past dividends. Results are presented in table 7. It is useful to note that they are very similar to those of table 6 . This is because the dividend process turns out to be close to a random walk, so that forecasts of future dividends are approximately equal to current dividends. For the United States, a bivariate autoregression using dividends and earnings instead of dividends and prices gives very similar results.

Figure 1 gives the behavior of stock markets during the 1970-84 period. Qualitatively, the behavior is not surprising. Except for Japan, the 1978-82 period, which we have shown above to be one of sharply increasing real interest rates, is also one of declining real stock prices. The period starting in 1982, which is characterized by slightly declining long rates and various degrees of economic recovery, is one of sharp stock price increases. However, table 6 shows that dividend-price ratios are uniformly lower in 1984:2 than in 1978 across all countries. Also, required returns (table 7), which can be thought of as cyclically adjusted dividend-price ratios, mostly show no increase in these ratios between 1978 and 1984. This is surprising in light of the sharp increases in the required real rates of return on bonds during the period.

To account for this difference between dividend-price ratios and real 
Table 7. Required Real Rates of Return on Equities, 1978-84:1

Percent

\begin{tabular}{lcccccc}
\hline & \multicolumn{2}{c}{ United States } & & & & \\
\cline { 2 - 3 } Period & $\begin{array}{c}\text { Using } \\
\text { prices }\end{array}$ & $\begin{array}{c}\text { Using } \\
\text { earnings }\end{array}$ & France & $\begin{array}{c}\text { West } \\
\text { Germany }\end{array}$ & $\begin{array}{c}\text { United } \\
\text { Kingdom }\end{array}$ & Japan \\
\hline 1978 & 4.3 & 4.3 & 6.2 & 3.4 & 4.9 & 1.1 \\
1979 & 4.7 & 4.4 & 5.2 & 4.0 & 4.8 & 1.2 \\
1980 & 4.8 & 4.6 & 5.1 & 4.6 & 5.4 & 1.5 \\
1981 & 5.1 & 4.6 & 6.1 & 5.4 & 5.4 & 1.5 \\
1982 & 5.1 & 5.2 & 6.7 & 5.0 & 5.4 & 1.5 \\
1983 & 4.2 & 4.2 & 5.9 & 4.3 & 4.6 & 1.8 \\
$1984: 1$ & 4.3 & 4.3 & 5.2 & 2.6 & 4.8 & 1.6 \\
\hline
\end{tabular}

Source: Calculations, as described in text, based on data from $O E C D$ Financial Statistics.

a. Forecasts for dividends, $D_{t, t+i}$, are obtained by generating forecasts at $t$ for $i$ periods ahead from a bivariate autoregression (4) for dividends, $D$, and prices, $P$, based on the last twenty-four quarters. The variables $D_{t}$ and $P_{t}$ are not included in the information set at $t$. The U.S. series was calculated with dividends and earnings as well as dividends and prices. The prediction equation for Italy was unstable and is not reported. Values for 1978-83 are annual averages of quarterly estimates.

rates on bonds, it is useful to start with the following relation that is implied by arbitrage between bonds and stocks:

$$
D / P=R+\gamma-x
$$

where $D / P$ is the dividend-price ratio, $R$ is the long real rate on bonds, $\gamma$ is the risk premium required by portfolio holders to hold equities rather than long bonds, and $x$ is the expected rate of growth of real dividends. ${ }^{2}$ If both $\gamma$ and $x$ were equal to zero, $D / P$ would equal $R$. If $x$ and $\gamma$ had not changed from 1978 to $1984: 2, D / P$ and $R$ would have moved together; the divergent movements of $D / P$ and $R$ imply that either $\gamma$ or $x$ has changed. Using 1978 and 1984:2 values for $R$ from table 4 and values of $D / P$ from table 6 , we get for the United States

$$
\begin{aligned}
\left(\gamma_{78}-x_{78}\right)-\left(\gamma_{84}-x_{84}\right) & =\left[(D / P)_{78}-R_{78}\right]-\left[(D / P)_{84}-R_{84}\right] \\
& =5.5 \text { percent. }
\end{aligned}
$$

2. This relation can be derived as a first-order approximation when portfolio holders arbitrage between assets up to given risk premiums. See Robert J. Shiller, John Y. Campbell, and Kermit L. Schoenholtz, "Forward Rates and Future Policy: Interpreting the Term Structure of Interest Rates," BPEA, 1:1983, pp. 173-224, for a discussion of such approximations in the case of bonds. A more precise definition of $R$ is that it the real rate on a bond of duration equal to that of the stock (see Shiller, Campbell, and Schoenholtz, "Forward Rates," also for a definition of duration). 
Therefore, if we assume that the risk premium has not changed since 1978, average expected growth of real dividends must be 5.5 percent higher in 1984 than in 1978. Equivalently, if expected growth of dividends is the same in 1984 as it was in 1978, the risk premium on equities must be 5.5 percent lower than in 1984 . Going through the same computation for other countries gives:

$$
\begin{array}{ll}
\text { France } & =5.0 \text { percent } \\
\text { West Germany } & =3.2 \text { percent } \\
\text { United Kingdom } & =5.7 \text { percent } \\
\text { Italy } & =1.8 \text { percent }
\end{array}
$$

Another way of showing the importance of these implications is to ask, What would the value of the stock market index be if both $\gamma$ and $x$ had not changed over the 1978-84 period while real interest rates rose as they did? Answer: the Dow Jones industrial index in the United States would be equal to 555 instead of 1200 ! Results would be nearly as dramatic for the other countries. ${ }^{3}$

\section{REAL EXCHANGE RATES}

Table 8 presents some information on the evolution of real exchange rates over the $1978-83$ period. The dramatic real appreciation of the dollar since 1978 is a prominent feature of recent experience. This appreciation has continued since the end of 1983, with the dollar rising in real terms by 4 percent between December 1983 and July 1984 relative to a trade-weighted basket of other currencies. The substantial appreciation of the yen relative to the European currencies is also noteworthy.

The behavior of the dollar provides strong evidence against at least one hypothesis about budget deficits. This is the notion that U.S. deficits will ultimately be monetized and lead to high rates of inflation. If such an expectation were pervasive, one would expect the dollar to decline,

3. Two caveats are in order here. The conceptually appropriate real rate $R$ is a longer rate than the medium-term real rate we have used. To the extent that the appropriate long real rate has moved less, the results overstate the change in $\gamma$ or $x$. The other caveat concerns the well-documented volatility of stock market prices (see, for example, Robert J. Shiller, "Stock Prices and Social Dynamics," BPEA, this issue) and the possibility that stock prices increase "too much" in recoveries. To the extent that 1978 and 1984 are comparable in the United States in terms of their cyclical position, our computation should be roughly unaffected by this problem. 
Table 8. Real Appreciation of the Dollar, 1978-84:1 ${ }^{a}$

Index, $1980=100$

\begin{tabular}{lcrccrr}
\hline Period & $\begin{array}{c}\text { United } \\
\text { States }\end{array}$ & France & $\begin{array}{c}\text { West } \\
\text { Germany }\end{array}$ & $\begin{array}{c}\text { United } \\
\text { Kingdom }\end{array}$ & Italy & Japan \\
\hline 1978 & 104.7 & 91.0 & 103.6 & 72.2 & 88.2 & 137.5 \\
1979 & 100.5 & 95.9 & 105.6 & 80.2 & 95.0 & 116.2 \\
1980 & 100.0 & 100.0 & 100.0 & 100.0 & 100.0 & 100.0 \\
1981 & 114.7 & 94.6 & 89.6 & 103.0 & 93.4 & 109.9 \\
1982 & 122.6 & 91.4 & 93.4 & 98.0 & 97.1 & 97.5 \\
1983 & 127.0 & 87.6 & 93.9 & 91.7 & 99.8 & 104.4 \\
$1984: 1$ & 131.1 & 85.7 & 92.0 & 91.6 & 100.4 & 108.9 \\
\hline
\end{tabular}

Source: IMF, International Financial Statistics, series 99by 110.

a. Effective exchange rates adjusted by deflators for value added in manufacturing.

not rise. The strength of the dollar confirms our conclusion that high nominal rates, at least in the United States, correspond to high real rates, not high inflationary expectations.

\section{Determinants of Real Rates}

The previous section documented that real interest rates are high worldwide. This is true of short and medium-term rates and probably of long rates as well. (For simplicity we shall refer to medium and long rates in this section as long rates; this does not mean that we are overlooking the ciistinction between the two.) Theory suggests that several different types of change in the economic environment can lead to increases in real rates. In this section we review these different types of change and assess their implications not only for real rates but for other asset prices as well. This will tell us what to look for in assessing which types of change are actually responsible for the high rates. Although we present the different types as alternatives, it is likely that a combination of factors is responsible for the behavior of real rates over the last six years.

As noted earlier we identify four potential explanations for high long real rates. In the first two, such rates portend high equilibrium real rates in the future. The first, rather pessimistic explanation concentrates on the role of reduced current and prospective saving in driving up interest rates; reduced saving may, for example, result from public dissaving 
through budget deficits. The second, more optimistic explanation focuses on the increased attractiveness of investment owing to increased profitability or reduced uncertainty; in this case, an increase in the current and prospective demand for funds drives up interest rates. The third explanation does not attribute high long rates to imbalances in the supply and demand for funds but rather to anticipation of sustained tight money. Under this explanation, long real rates portend a long period of high disequilibrium real rates. The fourth explanation points to the possibility that high rates on long bonds do not necessarily imply high expected short rates but may instead reflect an increase in the risk premium required to hold long bonds. This explanation holds that changes in asset prices and returns reflect portfolio shifts rather than shifts in saving or investment. We now examine each of these four explanations in more detail.

\section{SHIFTS IN THE SUPPLY OF FUNDS}

The first explanation is that of a decline in the current and prospective rate of saving. Such a decline can occur for many reasons, though most current discussions focus on public dissaving through budget deficits. Analytically, however, changes in budget deficits are essentially equivalent to other exogenous changes in saving. Thus we proceed in two steps, first looking at the dynamic effects of an adverse shift in saving and then returning to the relation of saving to deficits.

We must distinguish between the short-, medium-, and long-run effects of a saving shift. ${ }^{4}$ The short run can be analyzed in familiar IS-LM terms. A reduction in saving moves the IS curve outward, increasing short rates as long as monetary policy does not fully accommodate the increase in demand. The effect on long real rates and other asset prices depends on expectations of what happens in the medium and long run.

In the medium run the economy is supply constrained, so that the reduction in saving falls entirely on real interest rates, thereby leading to the presumption that short real rates increase further. In the long run the capital stock adjusts to a new lower level, because the decrease in

4. A formal analysis corresponding to the description in the text but emphasizing expectations effects is developed in Olivier J. Blanchard, "Dynamic Effects of a Shift in Savings; The Role of Firms," Econometrica, vol. 51 (September 1983), pp. 1583-91. 
saving at any level of capital and associated output implies a lower equilibrium level of capital. This lower capital stock is associated with higher marginal products and thus higher interest rates. How much higher interest rates will be in the long run depends on the long-run elasticity of capital demand with respect to the interest rate. A general point can be made here: very large changes in the capital stock are needed to get large changes in interest rates. If we assume that the longrun production function is approximately Cobb-Douglas, the long-run relation between the capital output ratio, $K / Y$, and the interest rate, $r$, is given by:

$$
K / Y=\frac{\alpha}{r+\delta}
$$

where $\alpha$ is the share of capital and $\delta$ the depreciation rate. If $\alpha=0.25$ and $\delta=0.07$, an increase of $r$ from 6 percent to 10 percent requires a decrease in $K / Y$ from 1.92 to 1.47 ; a decrease of this size is outside the range of historical experience.

How are these dynamics modified if the specific shift in saving takes the form of a long sequence of public dissaving, that is, of fiscal deficits? The budget deficit is often taken as a simple measure of the effect of fiscal policy on aggregate demand and saving. ${ }^{5}$ Such an approach leads one to conclude that large deficits have a large impact on aggregate demand and saving, but that the impact disappears as deficits are eliminated. Such an approach is justified only when current consumption decisions depend only on current income, as opposed to current and anticipated income. There is, however, substantial evidence that consumers are at least somewhat forward looking. ${ }^{6}$ This has two implications. The first is that consumers take partly into account the future increases in taxes implied by current deficits. Thus, to the extent that deficits are anticipated to decrease, looking only at current deficits may

5. This traditional approach recognizes that the effect will vary depending on the type of change in spending or in taxes. It also recognizes the endogenous nature of fiscal policy and focuses on full employment rather than actual deficits.

6. See, for example, Alan S. Blinder, "Temporary Income Taxes and Consumer Spending," Journal of Political Economy, vol. 89 (February 1981), pp. 26-53; Fumio Hayashi, "The Permanent Income Hypothesis: Estimation and Testing by Instrumental Variables," Journal of Political Economy, vol. 90 (October 1982), pp. 895-916; Robert E. Hall, "Stochastic Implications of the Life-Cycle Permanent Income Hypothesis: Theory and Evidence," Journal of Political Economy, vol. 86 (December 1978), pp. 971-87. 
lead one to overstate the effect of a fiscal program on current demand and saving. The second implication is that consumption depends on wealth, and wealth includes government debt. Thus, if and when deficits are closed, the effects on saving do not in fact disappear: the higher level of debt, owing to the accumulation of deficits, depresses saving until a lower level of capital is achieved. The appendix formalizes the above discussion and derives an index of fiscal stance; the index depends on both current and anticipated deficits as well as on the level of debt and characterizes the effects of a fiscal program on saving when consumers are forward looking.

We are now in a position to characterize the initial effects on asset returns and prices of a sequence of exogenous increases in deficits. Such a shift increases interest rates for a long period and therefore leads to an increase in real rates at all maturities. It also increases required returns on equity. The effect on stock prices is ambiguous; although required rates of return on equities increase, the temporary increase in output and profits may temporarily more than offset the effects of higher interest rates. ${ }^{7}$ Assuming that the economy returns relatively quickly to the equilibrium level of output, there is a strong presumption that deficits reduce stock prices.

Until now, we have not mentioned exchange rates, thus implicitly assuming that fiscal policy is the same across countries. What happens, however, if one country has a more expansionary fiscal policy than the others? There is a strong presumption that its exchange rate will appreciate, as predicted by the simple Mundell-Fleming model. ${ }^{8}$ Two factors work in favor of appreciation: the first is the increase in demand and thus the likely shift in relative demand toward domestic goods; the second is the increase in interest rates. Over time, the sustained trade deficits that arise from this appreciation generate forces tending to

7. See Olivier J. Blanchard, “Output, the Stock Market, and Interest Rates,” American Economic Review, vol. 71 (March 1981), pp. 132-43.

8. See Rudiger Dornbusch and Stanley Fischer, "The Open Economy: Implications for Monetary and Fiscal Policy," Working Paper 1422 (National Bureau of Economic Research, August 1984), and Jeffrey Sachs and Charles Wyplosz, "Real Exchange Rate Effects of Fiscal Policy," Working Paper 1255 (National Bureau of Economic Research, January 1984), for a detailed discussion. A. Giovannini, "The Exchange Rate, the Capital Stock and Fiscal Policy" (Columbia University, June 1984), and Willem Buiter, "Fiscal Policy in Open, Interdependent Economies"' (London School of Economics, May 1984), develop models consistent with that presented in the appendix. 
depreciation. Such trade deficits lead both to a transfer of wealth to foreign countries over time and to an increase in the share of domestic assets in both domestic and foreign portfolios. The first implies a gradual shift in relative demand away from domestic goods over time and thus depreciation. The second is likely to require both high domestic interest rates and, eventually, depreciation. Anticipations of the eventual depreciation may bring the actual depreciation forward in time.

This discussion has focused entirely on the effects of fiscal policy with the stock of money held constant in the short run and full employment assumed in the long run. It thus has considered only the "pure" effects of fiscal policy. It is important to recognize that the choice made by the fiscal authority may influence the course of monetary policy. For example, if the monetary authority is concerned with the level of output, fiscal expansions will induce monetary contractions. Alternatively, if it is concerned with the level of interest rates or the exchange rate, fiscal expansion will lead to monetary expansion. In either event, fiscal policy will have indirect effects on interest rates through its effects on monetary policy. We will return below to these possible indirect effects.

\section{SHIFTS IN THE DEMAND FOR FUNDS}

The second explanation we consider for high real interest rates is increased profitability. This does not include the normal cyclical improvement in profitability that takes place in a recovery but instead any increase in current and prospective profitability beyond the part attributable to cyclical movements in output. Recent discussions have suggested various reasons for such an increase in profitability. These range from vague notions of a new industrial revolution or of decreased uncertainty about the future to the effects of the slowdown in real wage growth in Europe or the decrease in business taxation in the United States. Because the effects of a decrease in business taxation are the easiest to characterize, we shall focus on them and briefly extend the analysis to the case of lower real wage growth.

In the short run, an increase in profitability has an effect on output and short-term rates similar to that of fiscal deficits: as long as monetary policy does not fully accommodate it, higher profitability increases investment and shifts the IS curve outward, leading to higher output and 
higher short rates. To determine what happens to long-term rates, we must again first examine the medium and long run.

In the medium run, output is determined by supply and, if capital has not increased enough, the increase in investment must take place at the expense of the other components of spending. There is therefore the presumption that real rates increase further as full employment is reached. However, real rates cannot rise more than after-tax marginal products; if they did, investment would be depressed and, if investment were low, equilibrium real rates needed to clear the goods market would be low, not high.

In the long run, higher investment leads to a higher equilibrium level of capital. This higher level of capital is associated with lower pretax marginal products. How much greater the capital stock and how much higher interest rates will be in the long run depends on the elasticity of the supply of capital to the business sector with respect to the return it yields. This in turn depends on the elasticity of saving and the extent to which capital is reallocated between business and nonbusiness uses. If the supply is inelastic, there will be little change in the capital stock, and interest rates will increase by nearly the amount of the decrease in taxation. If the supply is elastic, however, the adjustment will fall mainly on the capital stock, leading to more capital, lower pretax marginal products, and little change in interest rates.

Because business capital accounts for only about one-third of wealth, it is reasonable to expect substantial reallocations of capital in the face of profitability shocks. In addition, Summers has shown that under the life-cycle hypothesis there is a strong presumption that the elasticity of saving will be positive and large. Econometric evidence has not, however, been successful at uncovering such a large elasticity. ${ }^{9}$ Thus, it is difficult to assess the effect of increased profitability on interest rates in the long run. ${ }^{10}$

9. For a presentation of the theoretical argument and a discussion of econometric evidence, see Lawrence H. Summers, "Capital Taxation and Accumulation in a Life Cycle Growth Model," American Economic Review, vol. 71 (September 1981), pp. 53344. The available evidence on the elasticity of the supply of funds to the corporate sector is discussed in Lawrence H. Summers, "Taxation and Corporate Investment: A $q$ - Theory Approach," BPEA, 1:1981, pp. 67-127. Empirical work on the interest elasticity of saving is presented in Lawrence H. Summers, "Taxation, Savings, and the Rate of Return," Working Paper 995 (National Bureau of Economic Research, September 1982).

10. The description of the dynamic effects of business taxation given in the text is based on various formal models. Partial equilibrium models of the dynamic effects of 
It has been argued that currently Europe is suffering classical unemployment, a situation in which output is constrained by too high a level of real wages rather than too low a level of demand. How are the dynamics described above modified if the reason for increased profitability is not a reduction of business taxation but a current or prospective slowdown in real wage growth? The short-run dynamics may be quite different. Investment increases while the effect of income redistribution may decrease consumption. Employment and output supply are likely to increase. Whether the supply of output increases more than demand is ambiguous and so is the movement of short rates. These effects have been emphasized by Barro and Grossman. ${ }^{11}$ In the medium and long run, which are of more interest to us here, the main difference with business taxation is that, because of lower real wages, employment and output are now higher at any level of capital. This implies that in addition to the increase in the demand for funds, there is a partly offsetting increase in the supply of funds. Real rates may therefore be lower in the medium and long run than in the case of reduced business taxation.

We can now characterize the initial effects of a profitability increase on asset returns and prices. Real interest rates increase at all maturities and so do required rates of return on equities. The stock market, however, goes up: because it is investment demand that drives up real rates, expected profitability must have increased by more than interest rates. ${ }^{12}$

Can we predict what happens to the exchange rate if one country is

changes in business taxation are given in Andrew B. Abel, "Dynamic Effects of Permanent and Temporary Tax Policies in a Q Model of Investment," Journal of Monetary Economics, vol. 9 (May 1982), pp. 353-73, and in Summers, "Taxation and Corporate Investment." The general equilibrium effects of changes in business taxes are analyzed in Olivier J. Blanchard and Jeffrey D. Sachs, "Anticipations, Recession and Policy," Annales de l'INSEE vol. 47-48 (July-December 1982), pp. 117-44, using an intertemporal disequilibrium model with rational expectations, and in Andrew B. Abel and Olivier J. Blanchard, “An Intertemporal Model of Saving and Investment," Econometrica, vol. 51 (May 1983), pp. 675-92. See also C. Chamley, "Efficient Tax Reform in a Dynamic Model of General Equilibrium," Quarterly Journal of Economics, forthcoming, and K. Judd, "Short Run Analysis of Fiscal Policy in a Simple Perfect Foresight Model," Journal of Political Economy, forthcoming.

11. Robert J. Barro and Hershel I. Grossman, "A General Disequilibrium Model of Income and Employment," American Economic Review, vol. 62 (March 1971), pp. 82-93.

12. This ignores the difference between marginal and average $q$. See Fumio Hayashi, "Tobin's Marginal q and Average q: A Neoclassical Interpretation," Econometrica, vol. 50 (January 1982), pp. 213-24. This difference could be important if the increase in profitability affects existing capital differently from new capital, as in the case of an investment tax credit or acceleration of depreciation. 
affected more strongly than the others by the increase in profitability? We do not know of a formal model that answers the question, but the answer is likely to be that the effect is ambiguous. ${ }^{13}$ Higher interest rates and, if investment is mostly in the form of domestic goods, a relative shift in demand toward domestic goods both suggest appreciation. However, the anticipated increase in the relative supply of the domestic good after capital has accumulated suggests depreciation.

\section{TIGHT MONEY}

The third explanation also attributes high long real rates to expected high short rates. It does not, however, attribute high short rates to current or anticipated shifts in the full employment supply of, and demand for, funds but instead to tight money, which maintains interest rates at values higher than their equilibrium level.

There is no question that tight money can explain high short nominal and real rates. It is also generally accepted that money in the long run is neutral; thus tight money, either as a lower level or as a lower rate of growth of money, leads to lower prices and has no long-run effect on real rates. The relevant question is, How long is this long run?

As a logical matter, money has an effect on output as long as it has an effect on real rates. Thus we can look at the econometric evidence on the relation of output to changes in money supply. Macroeconometric models suggest that changes in money affect real output for a long period of time: the effects of an open market operation are sometimes still increasing after four years. ${ }^{14}$ More recent reduced-form evidence suggests shorter lags. Estimates by Barro, under the maintained hypothesis that only unanticipated money can affect output, still find that unanticipated money affects output for four years. Mishkin, using the same

13. Michael Bruno and Jeffrey Sachs, "Wages, Profits and Commodity Prices" (Harvard University Press, forthcoming), looks at the closely related question of the effects of an increase in the price of oil.

14. See, for example, Gordon Fisher and David Sheppard, "Effects of Monetary Policy on the US Economy: A Survey of Econometric Evidence," OECD Economic Outlook, Occasional Studies (December 1972), for a review of models. In the current DRI model, an increase in nonborrowed reserves has a multiplier effect on real GNP of 1.9 in the current quarter, a peak effect of 2.5 in the eighth quarter; the effect decreases to 2 after twenty-four quarters (DRI, "Properties of 1983 version of the DRI Model," Review of the U.S. Economy, April 1983). 
methodology but allowing both anticipated and unanticipated money effects, finds effects of unanticipated money for four years and effects of anticipated money for three years, although the latter become small and insignificant after two years. ${ }^{15}$

Other evidence is provided by the relation of interest rates to inflation. We have documented elsewhere the failure of nominal interest rates to adjust fully to changes in long-term expectations of inflation. ${ }^{16}$ This may be interpreted as evidence that money affects real rates for some period of time.

Additional evidence that monetary policy can affect long-term real rates comes from studies of the response of rates to money announcements. It is now well documented that unexpected increases in the money supply are associated with increases in interest rates at all maturities, which could be due to increases in expected inflation or in real rates. However, Engel and Frankel have shown that unexpected money is also associated with exchange rate appreciation. ${ }^{17}$ This suggests that increases in rates reflect increases in real rates. If expected inflation rose, one would expect exchange rate depreciation rather than appreciation.

Thus, when tight money is responsible for high real rates, we expect the term structure of real rates to be downward sloping for maturities longer than a few years. If tight money means lower money growth, the same should also be true of nominal rates, because both real rates and expected inflation are expected to be lower eventually. There is no ambiguity about what happens to stock prices. Required returns on equities increase with real bond rates and prospective dividends decrease together with output; stock prices must therefore decrease. There is also no ambiguity about the exchange rate if one country has tighter monetary policy than the others. Higher interest rates lead to initial real appreciation, which slowly disappears as rates return to their normal level.

15. Robert J. Barro, "Unanticipated Money, Output, and the Price Level in the United States," Journal of Political Economy, vol. 86 (August 1978), pp. 549-80; Frederic S. Mishkin, A Rational Expectations Approach to Macroeconomics: Testing Policy Ineffectiveness and Efficient-Markets Models (University of Chicago Press, 1983), table 6-5.

16. See Lawrence H. Summers, "The Non-adjustment of Nominal Interest Rates: A Study of the Fisher Effect," in James Tobin, ed., Macro-economics, Prices, and Quantities: Essays in Memory of Arthur M. Okun (Brookings, 1983), pp. 201-44.

17. Charles Engel and Jeffrey Frankel, "Why Interest Rates React to Money Announcements: An Explanation from the Foreign Exchange Market,' Journal of Monetary Economics, vol. 13 (January 1984), pp. 31-39. 


\section{PORTFOLIO SHIFTS}

The first three explanations attribute high long rates to anticipations of high short rates. They implicitly assume that the risk premiums associated with long bonds or equities remain constant. The fourth explanation questions the assumption of constant risk premiums.

The premium required to hold any asset increases if the risk associated with holding the asset increases. Finance theory suggests that the risk should be measured by the covariance of the asset return with the return on the market portfolio or more generally by the covariance of the asset return with movements in consumption. Assets with low returns in bad times have risk that cannot be diversified away and are therefore more risky. This covariance depends in turn on both the variances and covariances of all assets and on their relative supplies. Thus there are many developments that plausibly may have led to an increase in risk premiums on bonds, ranging from a relative increase in the proportion of public debt in portfolios to changes in the expected variability of inflation or in the feedback rules of monetary authorities.

If the increase in long real rates reflects an increase in risk premiums, it is difficult to predict what happens to stock returns and stock prices. This obviously depends on what causes the increase in risk premiums on bonds. An increase in the relative supply of bonds or an increase in the variance of inflation may have little or no effect on required stock returns. The same ambiguity extends to the real exchange rate. If, for example, the risk associated with holding domestic bonds increases for both domestic and foreign residents, there is no reason for the exchange rate to appreciate as domestic interest rates increase.

We have now surveyed four potential explanations for high real interest rates. Their differing implications for the level and slope of the term structure of real rates, for stock prices, and for exchange rates are summarized in table 9. The information in the table restricts the set of possible explanations for high rates. Neither tight money nor deficits can be the whole story, because the stock market has been relatively strong. Taken alone, the information in table 9 points toward profitability as a principal cause of high real rates. Before the importance of any of the four causes can be judged, however, it is necessary to examine them empirically. 
Table 9. Bonds, Stocks, and Real Exchange Rates under Alternative Hypotheses

\begin{tabular}{|c|c|c|c|c|c|}
\hline \multirow[b]{2}{*}{ Hypothesis } & \multicolumn{2}{|c|}{ Real rates on bonds } & \multicolumn{2}{|c|}{ Stock markets } & \multirow{2}{*}{$\begin{array}{c}\text { Real } \\
\text { exchange rates }\end{array}$} \\
\hline & Medium term & Long term & Rates of return & Prices & \\
\hline $\begin{array}{l}\text { Adverse shifts } \\
\text { in saving }\end{array}$ & $\begin{array}{l}\text { Strong } \\
\quad \text { increase }\end{array}$ & $\begin{array}{l}\text { Strong } \\
\text { increase } \\
\text { or increase }\end{array}$ & $\begin{array}{l}\text { Strong } \\
\text { increase }\end{array}$ & $\begin{array}{l}\text { Ambiguous } \\
\text { or decrease }\end{array}$ & Increase \\
\hline $\begin{array}{l}\text { Favorable shifts } \\
\text { in profitability }\end{array}$ & $\begin{array}{l}\text { Strong } \\
\quad \text { increase }\end{array}$ & $\begin{array}{l}\text { Strong } \\
\text { increase } \\
\text { or increase }\end{array}$ & $\begin{array}{l}\text { Strong } \\
\quad \text { increase }\end{array}$ & $\begin{array}{l}\text { Strong } \\
\text { increase }\end{array}$ & $\begin{array}{l}\text { In:rease } \\
\quad \text { or ambiguous }\end{array}$ \\
\hline Tight money & $\begin{array}{l}\text { Strong } \\
\quad \text { increase }\end{array}$ & Increase & Increase & Decrease & Strong increase \\
\hline Portfolio shifts & $\begin{array}{l}\text { Strong } \\
\quad \text { increase }\end{array}$ & $\begin{array}{l}\text { Strong } \\
\quad \text { increase }\end{array}$ & Ambiguous & Ambiguous & Ambiguous \\
\hline \multicolumn{6}{|l|}{ Addendum } \\
\hline $\begin{array}{l}\text { Actual move- } \\
\text { ments }\end{array}$ & $\begin{array}{l}\text { Strong } \\
\text { increase }\end{array}$ & Increase & Ambiguous & Increase & Strong increase \\
\hline
\end{tabular}

a. Alternative in entries indicates more than one response is predicted by theory.

\section{Adverse Shifts in Saving: Fiscal Policy}

Under the hypothesis that high real interest rates in our group of OECD countries reflect current and anticipated public dissaving, we must not focus on any single country's deficit but instead on the group's aggregate fiscal deficit or, more generally, on an aggregate measure of the group's fiscal stances. Under perfect capital mobility and barring distribution effects, equilibrium real rates in each country are determined by the aggregate deficit regardless of its own deficit. ${ }^{18}$ Under imperfect capital mobility, equilibrium real rates in each country will depend partly on its own deficit and partly on the aggregate deficit, but it remains true that the average level of rates will be related to the aggregate deficit. Thus, in this section a focus on aggregate measures is appropriate. However, when we come to consider a monetary and fiscal policy mix as the cause of high interest rates, we shall have to focus not only on the aggregate measure but on intercountry differences as well.

\section{CURRENT AND PAST DEFICITS}

The top part of table 10 gives the 1978-85 net budget balances for all levels of government, which for the United States means federal, state,

18. Distribution effects may arise if, for example, the countries with larger deficits have consumers with a higher propensity to save or have a lower proportion of liquidityconstrained consumers. 
Table 10. Budget Positions as a Percentage of GNP, 1978-85

\begin{tabular}{|c|c|c|c|c|c|c|c|}
\hline Year & $\begin{array}{l}\text { United } \\
\text { States }\end{array}$ & France & $\begin{array}{c}\text { West } \\
\text { Germany }\end{array}$ & $\begin{array}{c}\text { United } \\
\text { Kingdom }\end{array}$ & Italy & Japan & $\begin{array}{l}\text { Weighted } \\
\text { sum }\end{array}$ \\
\hline \multicolumn{8}{|c|}{ Unadjusted } \\
\hline 1978 & 0.2 & -1.9 & -2.5 & -4.2 & -9.7 & -5.5 & -2.4 \\
\hline 1979 & 0.6 & -0.7 & -2.7 & -3.2 & -9.5 & -4.8 & -1.9 \\
\hline 1980 & -1.2 & 0.2 & -3.1 & -3.5 & -8.0 & -4.5 & -2.5 \\
\hline 1981 & -0.9 & -1.8 & -3.8 & -2.8 & -11.9 & -4.0 & -2.4 \\
\hline 1982 & -3.8 & -2.6 & -3.5 & -2.1 & -12.7 & -3.4 & -3.3 \\
\hline 1983 & -3.9 & -3.2 & -2.7 & -3.7 & -11.8 & -3.1 & -3.8 \\
\hline 1984 & -3.1 & -3.5 & -1.4 & -2.8 & -12.4 & -2.3 & -3.2 \\
\hline 1985 & -3.7 & -3.5 & -0.4 & -2.4 & -12.9 & -1.6 & -3.2 \\
\hline \multicolumn{8}{|c|}{ Adjusted for inflation } \\
\hline 1978 & 1.6 & -1.0 & -2.3 & -0.3 & -2.5 & -5.2 & -0.8 \\
\hline 1979 & 2.4 & 0.3 & -2.3 & 2.6 & -0.4 & -4.3 & 0.2 \\
\hline 1980 & 0.5 & 1.4 & -2.4 & 3.6 & 4.2 & -3.2 & 0.2 \\
\hline 1981 & 0.7 & -0.6 & -3.0 & 2.0 & -1.2 & -3.0 & -0.5 \\
\hline 1982 & -2.8 & -1.3 & -2.7 & 1.5 & -2.4 & -2.8 & -2.3 \\
\hline 1983 & -3.1 & -2.0 & -2.2 & -1.4 & -1.6 & -2.7 & -2.6 \\
\hline 1984 & -2.2 & -2.3 & -0.8 & -0.7 & -4.4 & -1.6 & -1.8 \\
\hline 1985 & -2.5 & -2.4 & 0.3 & -0.1 & -6.3 & -0.8 & -1.9 \\
\hline \multicolumn{8}{|c|}{ Midcycle, adjusted for inflation } \\
\hline 1978 & 0.5 & -2.1 & -2.9 & -2.1 & -2.6 & -5.1 & -1.6 \\
\hline 1979 & 1.3 & -1.0 & -3.3 & 0.6 & -1.2 & -4.4 & -0.7 \\
\hline 1980 & 1.1 & 0.7 & -3.2 & 4.0 & 3.4 & -3.3 & 0.1 \\
\hline 1981 & 1.4 & -0.3 & -3.0 & 4.4 & -1.4 & -3.1 & 0.0 \\
\hline 1982 & -0.4 & -0.7 & -1.6 & 4.5 & -2.0 & -2.7 & -1.2 \\
\hline 1983 & -1.2 & -0.8 & -0.4 & 1.5 & 0.0 & -2.3 & -1.1 \\
\hline 1984 & -1.3 & -0.2 & 0.8 & 1.7 & -1.9 & -1.2 & -0.8 \\
\hline 1985 & -2.3 & 0.1 & 1.5 & 2.1 & -3.7 & -0.5 & -1.1 \\
\hline
\end{tabular}

Source: Data for 1978-83, OECD, "Structural Budget Deficits and Fiscal Stance," Working Paper 15 (Paris, July 1, 1984); for 1984-85, OECD Economic Outlook, no. 34 (July 1984).

a. Budget surpluses and deficits aggregated over all levels of government for each country. Minus sign indicates deficit. For the weighted sum, the weights are: $\mathrm{GNP}_{i} e_{i} / \Sigma_{j} \mathrm{GNP}_{j} e_{j}$, where $e$ is the exchange rate. Contemporaneous exchange rates are used for 1978-83, and 1983 exchange rates are used for 1984-85. Values for 1984-85 are mid1984 OECD estimates and forecasts.

and local, as a percent of GNP for the six OECD countries (1984-85 numbers are mid-1984 OECD estimates and forecasts). There is fiscal expansion in the United States, France, and Italy and contraction in the United Kingdom, West Germany, and Japan. As a result the aggregate deficit as a percent of the group's GNP (constructed using contemporaneous exchange rates) shows an increase of only 0.8 percentage points over the period, compared with 3.9 percentage points in the United States.

However, it is now well understood that official deficits do not measure correctly the change in real indebtedness of governments. To do so, the 
deficits must be adjusted for inflation by subtracting from the deficit the part of net nominal interest payments that is due to inflation. ${ }^{19}$ Inflationcorrected net budget positions as a percent of GNP are given in the middle part of table 10. The deficits are smaller than in the top part of table 10, with small aggregate surpluses in 1979 and 1980. Declining inflation but increasing debt levels imply that the path of the aggregate deficit is quite similar to that of the top part of table 10. The increase in the aggregate inflation-adjusted deficit is equal to 1.1 percentage points of GNP, compared with 4.1 percentage points for the United States. The conclusion that the inflation-adjusted aggregate deficit has not increased much during the period does not depend on our choice of 1978 as a starting year. The average inflation-adjusted deficit for $1970-78$ is 0.2 percent of GNP.

Anticipated short real rates depend not on current and past deficits but rather on future anticipated deficits. A first, simple, and crude proxy for future deficits is the current cyclically adjusted deficit. Thus we present midcycle inflation-adjusted budget positions in the bottom part of table 10. They measure what the net budget position would be if the economies were at their normal midcycle level. The bottom part of the table shows very clearly that the United States is a mirror image of other countries taken together: the U.S. deficits increased by 2.8 percentage points and the others decreased by 3.3 percentage points. Although we have focused on only six countries, the conclusion would be the same for the OECD as a whole; although some small countries (Denmark, Ireland) have experienced large increases in their adjusted deficit, their weight is too small to matter in the aggregate. ${ }^{20}$

\section{ANTICIPATIONS OF FUTURE DEFICITS}

Cyclically adjusted deficits are still only rough proxies for anticipations of future deficits. Such anticipations should be more than projec-

19. The official deficit might be more appropriate as a measure of the effect of policy on demand if consumers suffer from inflation illusion and treat nominal interest payments as real interest payments. For a discussion and tests using Italian data, see F. Modigliani, T. Jappelli, and M. Pagano, "The Impact of Fiscal Policy and Inflation on National Saving: The Italian Case'" (Massachusetts Institute of Technology, May 1984). For a discussion of inflation adjustments, see Robert Eisner and Paul J. Pieper, "A New View of the Federal Debt and Budget Deficits," American Economic Review, vol. 74 (March 1984), pp. 11-29.

20. Numbers for all OECD countries for the longer period 1971-83 are given in OECD, “Structural Budget Deficits and Fiscal Stance," Working Paper 15 (OECD, July 1984). 
tions of current policies; they should incorporate forecasts of employment growth and future fiscal policies; they should also consider that a rise in debt and associated interest payments over time will lead to larger deficits when full or normal employment is reached. Unfortunately, consistent forecasts that take these factors into account beyond 1985 are not available for most countries. They are available for the United States, however, from DRI, whose deficit forecasts incorporate anticipated deficit "downpayments" and other changes in policy. The DRI forecasts are to be distinguished from, and for our purposes preferred to, the widely used and cited projections of the Congressional Budget Office; as the $\mathrm{CBO}$ itself emphasizes, their projections assume that policy remains unchanged. The results of the different concepts represented by DRI and the CBO are illustrated in table 11, which compares their last four annual six-year anticipations of unified federal budget deficits. For 1980 and 1981, CBO projections showed substantial federal budget surpluses five years out owing to the fiscal drift built into the tax system; DRI more realistically predicted modest deficits. Likewise, in 1984 the DRI forecast again included policy shifts and showed a 1989 federal budget deficit of 3.4 percent of GNP, whereas the CBO obtained a 1989 deficit of 6.1 percent. We use the DRI forecasts as more useful in our context than the $\mathrm{CBO}$ projections, though it must be emphasized that DRI assumes there will be changes from current policy. As shown in the last column of table 11, the DRI calendar-year forecast of combined federal, state, and local government budget positions shows deficits peaking at 3.4 percent of GNP in 1985 and declining to 1.8 percent of GNP in 1989. Because inflation is predicted to be approximately constant during the period and employment is predicted to be nearly full by 1985 , neither inflation adjustment nor cyclical adjustment alters the forecast of a decreasing trend.

We do not have such long-term forecasts for the other countries. Announced medium-term strategies show no anticipated change in their fiscal stance. Given current forecasts of approximately constant unemployment, this suggests little change in cyclically adjusted deficits for Europe or Japan. Lower U.S. deficits and unchanged deficits in other countries suggest a slow decrease in the aggregate cyclically adjusted deficit after 1985. It seems that high real rates cannot be attributed to prospective aggregate deficits.

We have argued in the previous section that, to the extent that 
Table 11. U.S. Budget Positions as a Percentage of GNP: Annual CBO Projections and DRI Forecasts, 1980-89

\begin{tabular}{|c|c|c|c|c|c|c|c|c|c|c|c|}
\hline \multirow{3}{*}{$\begin{array}{c}\text { Fiscal } \\
\text { year }\end{array}$} & \multicolumn{10}{|c|}{ Unified federal budget position } & \multirow{3}{*}{$\begin{array}{c}1984 \\
\text { DRI, } \\
\text { total } \\
\text { gov- } \\
\text { ern- } \\
\text { ment }\end{array}$} \\
\hline & \multicolumn{2}{|c|}{1980} & \multicolumn{2}{|c|}{1981} & \multicolumn{2}{|c|}{1982} & \multicolumn{2}{|c|}{1983} & \multicolumn{2}{|c|}{1984} & \\
\hline & $\mathrm{CBO}$ & $D R I$ & $C B O$ & $D R I$ & $C B O$ & $D R I$ & $C B O$ & $D R I$ & $C B O$ & $D R I$ & \\
\hline 1980 & -1.6 & -1.6 & . . & $\cdots$ & $\cdots$ & $\cdots$ & $\cdots$ & $\cdots$ & $\cdots$ & $\cdots$ & . . \\
\hline 1981 & -0.8 & -2.0 & -1.7 & -2.5 & $\ldots$ & $\ldots$ & $\ldots$ & $\ldots$ & $\ldots$ & & $\ldots$ \\
\hline 1982 & 1.0 & -0.7 & -0.9 & -1.8 & -3.6 & -3.9 & $\ldots$ & $\ldots$ & $\ldots$ & $\ldots$ & $\ldots$ \\
\hline 1983 & 2.8 & -0.5 & 0.5 & -1.5 & -4.6 & -3.8 & -6.0 & -6.4 & $\ldots$ & $\ldots$ & $\ldots$ \\
\hline 1984 & 4.7 & -0.3 & 1.9 & -1.6 & -5.0 & -3.4 & -5.6 & -5.8 & -5.3 & -5.1 & -3.1 \\
\hline 1985 & 6.6 & -0.3 & 3.1 & -1.0 & -5.0 & -2.5 & -5.6 & -5.2 & -5.0 & -5.0 & -3.4 \\
\hline 1986 & $\ldots$ & $\cdots$ & 4.3 & -0.7 & -5.1 & -2.3 & -5.6 & -4.7 & -5.1 & -4.5 & -3.0 \\
\hline 1987 & $\ldots$ & $\ldots$ & $\ldots$ & $\ldots$ & -5.0 & -2.1 & -5.6 & -4.0 & -5.4 & -4.4 & -2.8 \\
\hline 1988 & $\ldots$ & $\ldots$ & $\ldots$ & $\ldots$ & $\ldots$ & $\ldots$ & -5.6 & -3.2 & -5.6 & -3.8 & -2.1 \\
\hline 1989 & $\ldots$ & $\ldots$ & $\ldots$ & $\ldots$ & $\ldots$ & $\ldots$ & $\ldots$ & $\ldots$ & -6.1 & -3.4 & -1.8 \\
\hline
\end{tabular}

Source: Congressional Budget Office, Baseline Budget Projections for Fiscal Years 1985-1989, A Report to the Senate and House Committees on the Budget, Part II (Government Printing Office, 1984), p. 7, and previous issues; DRI, Long-Term Review of the U.S. Economy (DRI, March 1984), and previous issues.

a. Minus sign indicates deficit.

b. Sum of DRI forecasts of federal, state, and local government budget positions in the national income accounts, divided by DRI forecasts of GNP (calendar years).

consumers are forward looking, the effect of fiscal policy on demand in a given year is not well measured by current deficits. The effect of fiscal policy in 1984 on aggregate demand in 1984, for example, depends on both current and anticipated deficits and also on the level of debt. In the first part of the appendix we have derived a theoretical index of fiscal stance along these lines. In the second part of the appendix we construct empirical counterparts to this index for all six countries for 1978 to 1989 ; 1978 to 1984 values are estimates, 1985 to 1989 values are forecasts. For each year, the index depends on the current level of debt and the forecasts of primary deficits over the following ten years. The results confirm the conclusions reached above. The U.S. index increases from 1978 to 1983 , declines slightly in 1984, and is then anticipated to decrease slowly over time. In Europe, the indexes for West Germany and the United Kingdom show steady past, current, and anticipated decreases. France and Italy show increases over time; in both cases this is due to steady increases in their debt to GNP ratios. The index for Japan shows a steady decrease. The aggregate index shows little change over the period, except for a temporary increase in 1983; it is anticipated to be lower in 1989 than in 1978. 
On balance, therefore, we find no evidence that fiscal policy in the OECD as a whole is responsible, through its effect on saving, for high long real rates. This does not rule out, however, that a fiscal-monetary mix may be partly responsible for these rates, and we shall turn to this issue below.

Fiscal policy is not the only factor that may shift saving. Another potential candidate is a shift in saving behavior of the oil exporting countries. The combined current account of OPEC countries has gone from approximate balance in 1978 to a surplus of $\$ 111$ billion in 1980 , and then back to deficits in 1982; deficits of $\$ 12$ billion are predicted for $1985 .{ }^{21}$ Taking the current account of OPEC countries as a percent of the GNP of the group of countries we consider, the change in current account balance corresponds to a swing from a surplus of 0.1 percent in 1978 to a surplus of 1.8 percent in 1980 and back to a deficit of 0.2 percent in 1985. Although the swing from 1980 to 1985 is a large one, no one in 1980 thought that the OPEC surplus would remain at such a high level. The decrease from 1980 was at least partly anticipated and cannot be blamed for the increase in real rates after 1980.

\section{Favorable Shifts in Profitability}

The conceptual discussion has shown that an explanation based on favorable shifts in profitability has considerable appeal. Such shifts, if they occurred, can explain both high real interest rates, because of the increased demand for funds, and the strong stock market, because of higher prospective profits. A number of plausible causes for such shifts have been proposed. Some are specific to some countries, suggesting different stock market and investment performances across countries; some apply to all countries.

One candidate for causing a shift to greater profitability is the general decrease in business taxation in the United States since $1981 .{ }^{22}$ The pace at which the investments could be depreciated was dramatically in-

21. OECD Economic Outlook, no. 34 (July 1984), table 54.

22. The argument that high real rates were due to the 1981 tax changes and were therefore likely to remain was made as early as 1982 by Stanley Fischer and Steven Sheffrin in "Why Long Term Real Interest Rates Will Stay High" (Massachusetts Institute of Technology, October 1982). 
creased in 1981. In addition, reduced inflation has raised the real value of historical depreciation allowances. The effect on the world real interest rate, however, is likely to be small: Auerbach has estimated that the effective tax rate on corporate investment declined from 31.9 percent in 1980 to 17.7 percent in 1981 and 24.6 percent in $1982 .{ }^{23}$ This represents an increase of 73 basis points in the after-tax return to corporate investment between 1980 and 1982, assuming a constant pretax marginal product of capital of 10 percent. This increase should not translate point for point into higher interest rates. At market value, U.S. corporate capital represents only one-fifth of U.S. wealth and a much smaller share of world wealth. Feldstein and Summers have estimated that each 1 percentage point increase in the after-tax return to corporate capital raises real interest rates by 25 basis points. ${ }^{24}$ This number was obtained by estimation over the period 1954-76; the greater integration of capital markets since then suggests an even smaller effect on real rates now. Overall, the effect of U.S. business tax cuts on the world real rate cannot be very large.

Another class of candidates includes decreases in factor prices and increases in productivity. Two recent studies have examined the recent behavior of productivity and have found no evidence that, after cyclical adjustment, productivity growth has recently increased in the United States. ${ }^{25}$ Some factor prices, however, have declined. For the group of European countries we consider, real unit labor costs declined 0.6 percent in 1982 and 1.2 percent in 1983 . They are projected to decline a further 0.9 percent in $1984 .^{26}$ The price of oil has also declined. The real spot market price of oil to U.S. users has decreased 25 percent from its 1981-84:1 high. However, as a consequence of real dollar appreciation, there has been little or no change in the real price of oil for the other countries we are looking at. These decreases in factor prices should have improved current profitability and may also have led to anticipations of

23. See table 4 in Alan J. Auerbach, "Corporate Taxation in the United States," BPEA, 2:1983, pp. 451-505.

24. Martin Feldstein and Lawrence Summers, "Inflation, Tax Rules, and the LongTerm Interest Rate," BPEA, 1:1978, pp. 61-99.

25. Peter K. Clark, "Productivity and Profits in the 1980s: Are They Really Improving?"' BPEA, 1:1984, pp. 133-67, and Robert J. Gordon, "Unemployment and Potential Output in the 1980s," $B P E A$, this issue.

26. European Economy, Annual Economic Report no. 18 (European Community, November 1983), table 3.5. 
higher future profitability. Assessing their potential quantitative effect is not something we shall attempt.

The last class of candidates includes decreases in uncertainty owing to the decrease in inflation or to the emergence of conservative governments in the United States, the United Kingdom, and West Germany. These may well have an effect; they are, however, difficult to quantify.

A test of the hypothesis that business prospects are bright involves the performance of investment. Investment spending has been unexpectedly strong in 1983 and 1984 in most countries. ${ }^{27}$ The question therefore arises of whether this is due to unexpected strength in output or instead to other shifts in anticipated profitability. In order to resolve this issue, we run for each country, over the 1962:3-1982:4 period, the following regression:

$$
\ln I_{t}=a_{0}+\sum_{i=0}^{6} b_{i} \ln Y_{t-i}+u_{t}
$$

where

$$
u_{t}=\rho_{1} u_{t-1}+\rho_{2} u_{t-2}+\epsilon_{t} .
$$

The variable $I_{t}$ is real gross private fixed investment and $Y_{t}$ is real GNP. This regression should not be thought of as a structural investment equation but as an equation characterizing the movement of investment given output. We then construct forecasts for 1983:1 to 1984:1 using dynamic simulations, that is, simulations using actual values of GNP and lagged forecast errors for $u_{t-1}$ and $u_{t-2}$. Under the hypothesis that there has been no shift in profitability, high real rates imply that investment spending should be low given the level of output. Thus we would expect negative forecast errors during that period. These forecast errors are reported in table 12 together with the standard errors of the regressions. Forecast errors are positive and often individually significant for the United States, West Germany, and Italy. Forecast errors alternate in sign in France, the United Kingdom, and Japan. In no country is there a consistent pattern of negative forecast errors.

These results suggest an underlying shift in profitability or investment uncertainty; otherwise it is difficult to reconcile high real rates and the behavior of investment. This conclusion holds with particular strength

27. See, for example, "Business Survey Results," European Economy, Supplement B, no. 7 (European Community, July 1984). 
Table 12. Errors in Dynamic Forecasts of Investment, 1983:1-84:1 ${ }^{a}$

Percent

\begin{tabular}{|c|c|c|c|c|c|c|}
\hline Period & $\begin{array}{l}\text { United } \\
\text { States }\end{array}$ & France & $\begin{array}{c}\text { West } \\
\text { Germany }\end{array}$ & $\begin{array}{c}\text { United } \\
\text { Kingdom }\end{array}$ & Italy & Japan \\
\hline 1983:1 & 1.9 & 2.3 & -0.4 & 1.8 & 2.0 & 0.4 \\
\hline 2 & 1.7 & -0.6 & 1.1 & -1.1 & 4.4 & 0.9 \\
\hline 3 & 3.4 & -0.3 & 4.8 & -0.1 & 5.6 & -0.1 \\
\hline 4 & 7.8 & 1.2 & 5.4 & 2.9 & 4.8 & 1.1 \\
\hline 1984:1 & 7.8 & 1.4 & $\ldots$ & $\ldots$ & $\ldots$ & $\ldots$ \\
\hline
\end{tabular}

Addendum:

Standard deviation

for the forecast

error

1.6

1.3

2.8

3.1

1.6

1.6

Source: Calculations based on OECD data.

a. The forecast error, $\epsilon_{l}^{*}$, is constructed as follows:

$$
\begin{aligned}
& \epsilon_{t}^{*}=\ln I_{t}-a_{o}^{*}-\sum_{i=0}^{6} b_{l}^{*} \ln Y_{t-i}-\rho_{1}^{*} u_{t-1}^{*}-\rho_{2}^{*} u_{t-2}^{*}, \\
& u_{t}^{*}=\rho_{1}^{*} u_{t-1}^{*}+\rho_{2}^{*} u_{t-2}^{*}+\epsilon_{t}^{*},
\end{aligned}
$$

where $I$ denotes real investment, and $Y$ denotes real output. Asterisks denote estimated value. Real investment is seasonally adjusted and defined for each country as follows: United States, real fixed nonresidential investment; West Germany, real gross domestic fixed investment; Italy, United Kingdom, and France, real gross fixed capital formation; Japan, real gross private fixed investment. Output for all countries is real gross national product.

for the more recent part of the period. The estimated residuals for the earlier period, 1980-82, show no consistent pattern, nor do the forecast errors for that period if we estimate investment equations over the period 1963-80 and generate dynamic forecasts for 1980-84.

\section{Tight Money}

The explanations we have considered so far have focused on real rather than monetary factors. We now turn to the role of tight money in explaining high long real rates. It seems very clear that tight money plays a major role in explaining the increase in real rates through 1982. Direct, nonquantitative evidence on changes in monetary policy for the United States and the United Kingdom is plentiful. Although rates of changes of monetary aggregates across countries do not consistently decrease, shifts in relative demands for $\mathrm{M} 1$ and $\mathrm{M} 2$ can easily explain the divergent movements between the different aggregates. If one makes the hypothesis that monetary policy determines short-term nominal rates, then the large increase in short nominal rates in 1980 , documented in table 2 , is 
prima facie evidence of tight money. The only question is whether the increase in long real rates up to 1982 can be attributed entirely to tight monetary policy. The studies of the relation between short and long nominal rates during the period are relevant here. Several studies have shown that the pre-1979 dynamic relation between short and long nominal rates did break down after $1979 .{ }^{28}$ Given short nominal rates, long nominal rates increased in 1980 and 1981 far more than would have been predicted by term-structure equations. This does not imply that tight money was not fully responsible for the increase in long rates. If the change in monetary policy was indeed perceived as a change in regime by financial markets, we would expect the normal term-structure relation to underpredict the reaction of long nominal rates to such a change in policy. ${ }^{29}$

The more difficult question is whcther tight money is largely or at least partly responsible for high real rates since 1982. Two explanations of long real rates place responsibility on the fiscal-monetary mix. The first explanation can be described as loose U.S. fiscal policy, tight European monetary policy. We saw earlier that there has been little or no change in aggregate fiscal policy; this explanation focuses instead on the divergence between U.S. and other fiscal policies. In the absence of tight monetary policy, these divergent movements in fiscal policy would have had offsetting effects on the world long real rate but cumulating effects on the real exchange rate: fiscal contraction outside of the United States and fiscal expansion in the United States are both likely to lead to real U.S. appreciation. Thus, in order to avoid further depreciation and inflationary pressure, Europe and Japan have used tight money to increase their long real rates. Under this interpretation, high U.S. long rates are due to expansionary fiscal policy while high long rates outside the United States are due to tight money. Also under this interpretation, Europe's increasing reluctance to use tight money because of its adverse output effects together with the decrease in inflationary pressure that has occurred has led Europe in 1984 to accept lower long rates and further depreciation.

The second explanation can be described as loose U.S. fiscal policy,

28. See, for example, Olivier J. Blanchard, "The Lucas Critique and the Volcker Deflation," American Economic Review, vol. 74 (May 1984, Papers and Proceedings, 1983), pp. 211-16, and Richard H. Clarida and Benjamin M. Friedman, "Why Have ShortTerm Interest Rates Been So High?" BPEA, 2:1983, pp. 553-85.

29. For a formal argument, see Blanchard, "The Lucas Critique." 
tight anticipated U.S. monetary policy. Even if aggregate fiscal policy is constant, fiscal expansion in the United States implies an increase in U.S. aggregate demand, while fiscal contraction elsewhere implies a decrease in aggregate demand outside of the United States. The United States is, however, well along in its recovery, and a period of sustained tight money may be needed as the economy approaches full employment. Given a desire on the part of Europe and Japan to avoid further depreciation of their currencies, money is also anticipated to be tight in the rest of the world, leading to high real rates there as well. This fiscalmonetary mix can also explain the continuing strength of the dollar.

These two explanations can be interpreted as linking high real rates ultimately to U.S. budget deficits. But the channel is very different from that explored earlier. It is the divergence in fiscal policies together with its implications for the real exchange rate and with monetary reaction functions that leads to high real rates. These explanations are difficult to prove or disprove; but there is little doubt that tight money is in some measure responsible for current high long real rates.

\section{Portfolio Shifts}

We turn now to the possibility that high real rates or, more generally, recent movements in asset prices and returns are partly attributable to changes in risk premiums. We look more specifically for evidence that risk premiums on bonds have increased or that risk premiums on equities have decreased.

We start by constructing a simple measure of risk that is both intuitive and suggested by finance theory. This measure is the covariance between the rate of change of consumption and the ex post rate of return on an asset: an asset with high returns when consumption is low provides a hedge and therefore requires a low expected return, a negative risk premium. ${ }^{30}$ In general, the more procyclical the asset return, the higher the risk premium.

In figure 2 we present time series for the estimated rolling covariances

30. Maximization of expected utility implies that the appropriate measure of risk is the covariance between the realized marginal rate of substitution and the ex post rate of return on the asset; the covariance we consider is a close approximation to this covariance. See, for example, L. Hansen and K. Singleton, "Stochastic Consumption, Risk Aversion and the Temporal Behavior of Asset Returns," Journal of Political Economy, vol. 91 (April 1983), pp. 249-65. 
Figure 2. Rolling Covariance of Real Holding Returns on Bonds with Consumption Changes, 1973-84
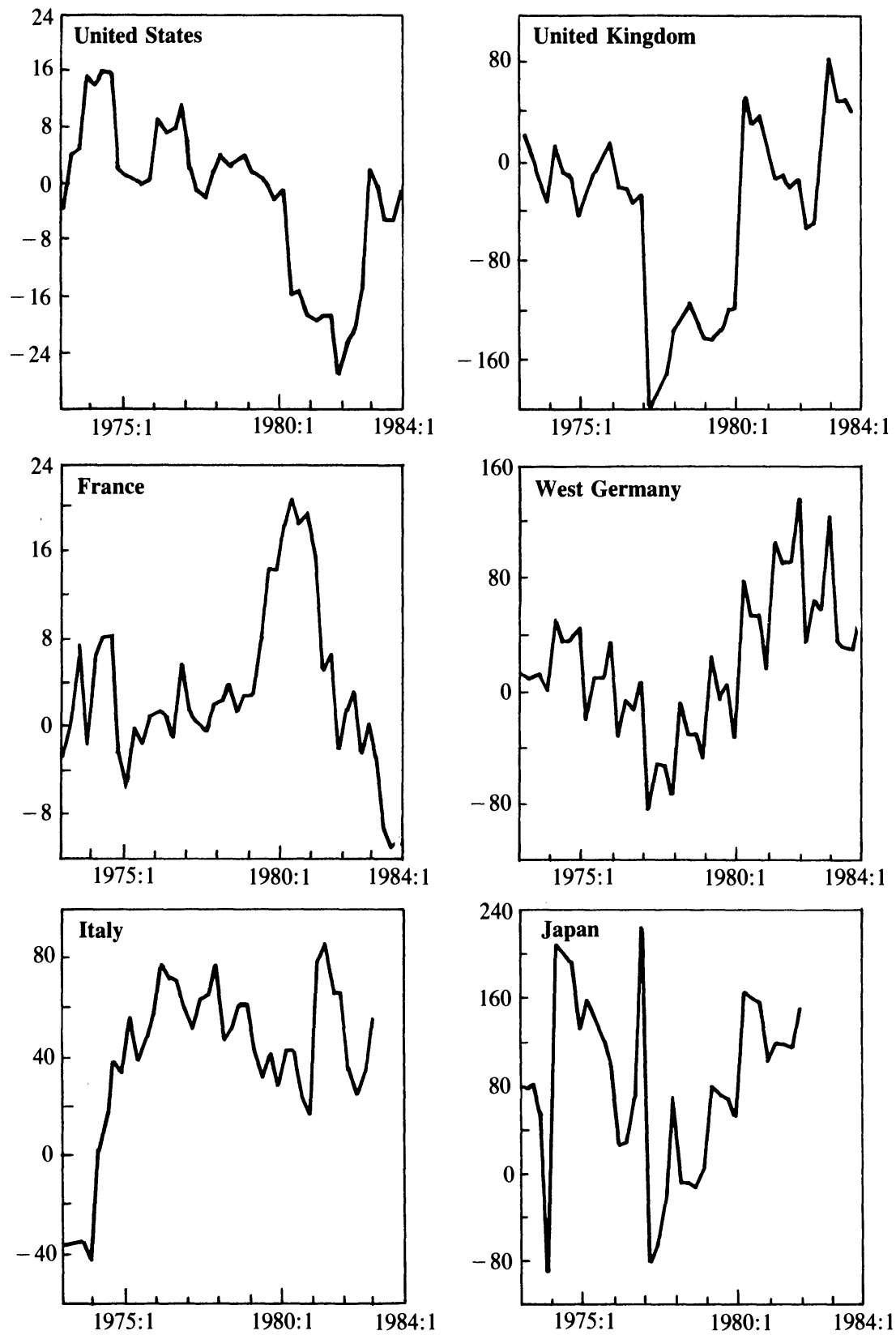

Source: Bond data, OECD Financial Statistics, various issues. Consumption data, OECD, Ouarterly National Accounts, various issues. Data for the United States extend to 1984:1; for the United Kingdom, 1983:3; for France and West Germany, 1983:4; for Italy, 1982:4; for Japan, 1982:1.

a. Rates of return and consumption changes are in percent at annual rates. Rates of return are deflated by the domestic CPI. 
between the rate of change of consumption and the real rate of return on medium-term bonds for all six countries. In each case, the real rate of return is computed using the domestic CPI. ${ }^{31}$ The covariance at any time $t$ is computed using observations from the last twelve quarters. The main characteristic of figure 2 is the diversity of movements across countries. Apart from a small increase in the United States after 1981, there is no evidence of an increase in the risk of bonds measured this way.

Figure 3 performs the same exercise for the covariance between the rate of change of consumption and the real rate of return on stocks. Again, no consistent pattern emerges. The U.S. covariance goes up after 1979 rather than down as would be required to explain the strength of the stock market. No common trend emerges for other countries.

Examination of these covariances therefore does not reveal either increases in risk for bonds or decreases in risk for stocks. There are, however, a few reasons to doubt that these covariances are accurate measures of risk. One reason is conceptual: the use of aggregate consumption is correct only if all consumers have the same portfolio choices available to them so that no consumer is liquidity constrained. The other reasons are technical: because of data limitations, our empirical measure of consumption is consumption expenditures rather than the more appropriate consumption services; also because of data limitations, we are forced to use time averages for consumption and thus also for stock and bond returns, whereas theory is about consumption at points in time. For these reasons, the estimated covariances may be noisy indicators of risk.

To go further, we turn to the pricing formulas implied by the more restrictive standard capital asset pricing model. This model implies that equilibrium expected returns on risky assets are given by

$$
\left(R_{i t}-r_{t}\right)=a\left(\sum_{j=1}^{n} \sigma_{i j} S_{j t}\right),
$$

where $R_{i t}$ is the equilibrium expected rate of return on asset $i$ for period $t$, and $r_{t}$ is the riskless rate. The coefficient $a$ is a weighted average, with positive weights, of the agents' coefficients of absolute risk aversion.

31. We look therefore at riskiness in each country from the point of view of the domestic investor. We could have computed instead the measure of risk relevant for the U.S. investor holding domestic or foreign bonds by using for all cases U.S. consumption and the real rate in terms of the U.S. consumption basket. 
Figure 3. Rolling Covariance of Real Holding Returns on Stocks with Consumption Changes, 1973-84
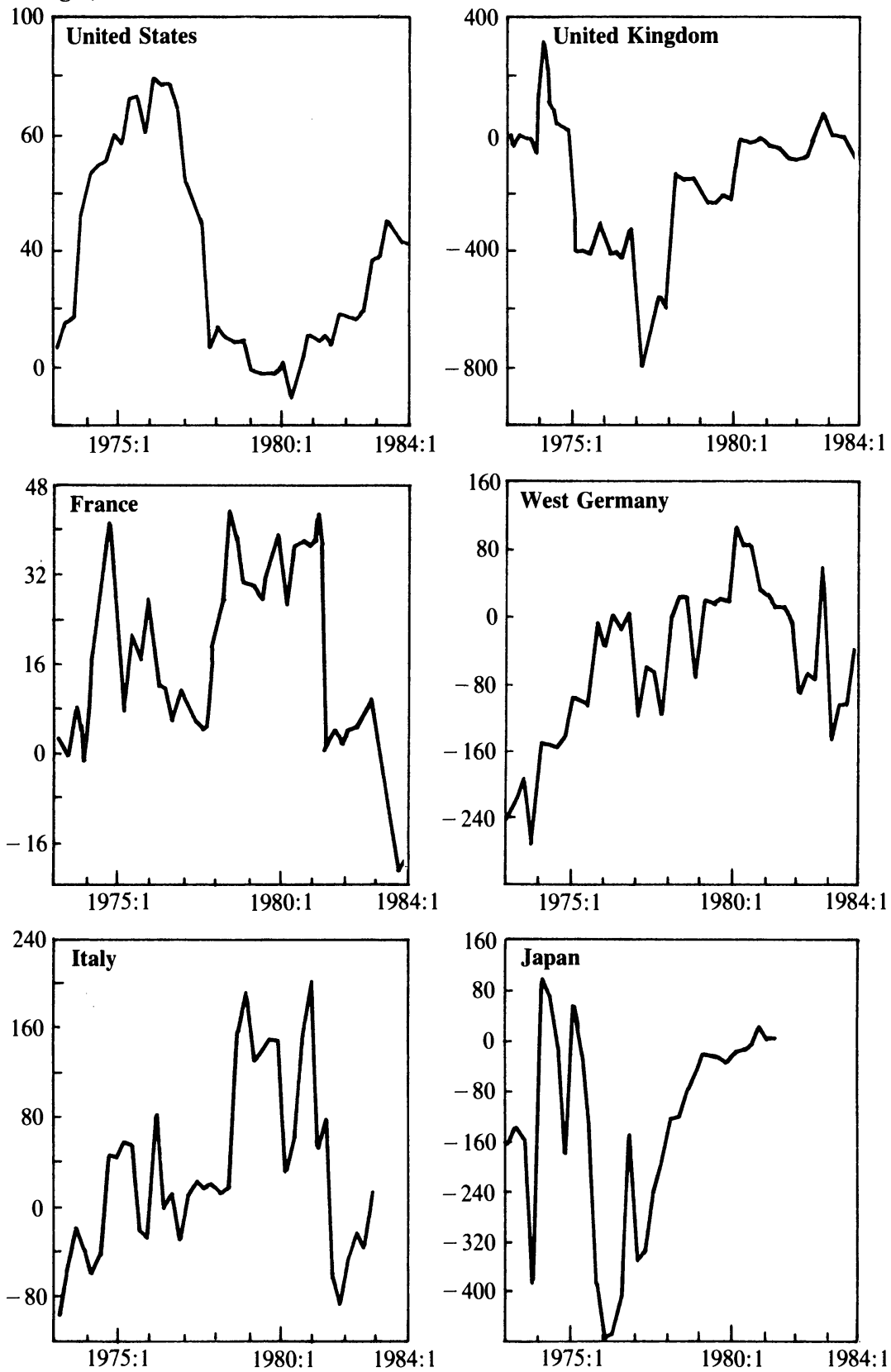

Source: Stock data, OECD Financial Statistics, various issues. Consumption data, same as figure 2 . Data for the United States extend to 1984:1; for the United Kingdom, France, and West Germany, 1983:4; for Italy, 1982:4; for Japan, 1982:1.

a. Units are as in figure 2 . 
The variable $\sigma_{i j}$ is the covariance of the rate of return on asset $i$ with the rates of return on the other assets $j=1, \ldots, n$. Last, $S_{j t}$ is the value of the supply of asset $j$ at time $t .{ }^{32}$

This model implies that changes in the risk premium associated with any asset, that is, its expected return in excess of the riskless rate, will come either from changes in relative supplies or from changes in covariances. For example, what is the effect of an increase in the supply of asset $i, S_{i t}$, on $R_{j t}$, the required return on asset $j$ ? The answer depends partly on what happens to the coefficient $a$ as the supply $S_{i}$, and therefore wealth, increases. If, for example, we assume constant relative risk aversion, with relative risk aversion coefficient $k$, the above equation becomes

$$
\left(R_{i t}-r_{t}\right)=k\left(\sum_{j=1}^{n} S_{j t}\right)-1\left(\sum_{j=1}^{n} \sigma_{i j} S_{j t}\right)
$$

so that

$$
\frac{\mathrm{d} R_{j t}}{\mathrm{~d} S_{i t}}=\left(\sum_{j=1}^{n} S_{j t}\right)-1\left[k \sigma_{i j}-\left(R_{j t}-r_{t}\right)\right] .
$$

An increase in the supply of any asset therefore has two effects on equilibrium rates of return. The first is that increasing the relative supply of this asset increases the required return on this asset and on all the assets that are close substitutes. This effect is measured by $k \sigma_{i j}$ : if the covariance $\sigma_{i j}$ is positive, the required return on asset $j$ increases with an increase in $S_{i}$. The second effect is that an increase in $S_{i}$ increases wealth, increasing the demand for all assets and decreasing their required returns; this effect is measured by $-\left(R_{j t}-r_{t}\right)$ for asset $j$. The net effect is, in general, ambiguous.

Two recent empirical studies have estimated the variances, covariances and expected returns required to look at the effects of changes in relative asset supplies on equilibrium rates of return. ${ }^{33}$ Both find a

32. For a statement of assumptions and a derivation, see Robert C. Merton, "An Intertemporal Capital Asset Pricing Model," Econometrica, vol. 41 (September 1973), pp. 867-87.

33. J. Frankel, "Empirically Estimated Portfolio Crowding-out" (University of California, Berkeley, July 1983), and Benjamin Friedman, "Implications of Debt-Equity Substitutability for Interest Rates and Corporate Financing"' (National Bureau of Economic Research, August 1984). Both studies assume, however, that U.S. portfolio holders hold only domestic assets. 
positive but small covariance between rates of return on long bonds and equities. They both find, however, that when the wealth effect is taken into account, an increase in the supply of long-term government bonds increases the risk premium on bonds but decreases the risk premium on equities. ${ }^{34}$ They also find that for plausible magnitudes of change in supplies and of coefficients of relative risk aversion, the two effects are small. Moreover, the change in relative supplies over the last six years is smaller than is commonly perceived. Considering only U.S. assets, the projected increase in government debt over the next three years, for example, is approximately equal to the increase in the market value of equity over the last eighteen months. A more systematic assessment of relative effects, beyond the scope of this paper, would require taking account of the possibility for domestic residents to hold both domestic and foreign assets.

Another factor which may have increased risk premiums on bonds is an increase in the variances and covariances of asset returns. Bodie, Kane, and McDonald have recently argued that the increase in the variance of bond returns in the United States has, by raising their covariance with the market portfolio, increased the risk premium on bonds and thus their expected return..$^{35}$ Using an estimate of relative risk aversion of 3.5, they conclude that increased risk could explain an increase of 370 basis points in the one-period rate of return on bonds of eight-year duration.

Figure 4 presents time series for the rolling variances of real rates of return on medium-term bonds for all six countries. The variance at time $t$ is computed using observations from the last twelve quarters. Results for the United States are similar both qualitatively and quantitatively to those of Bodie, Kane, and McDonald showing a sharp increase in the variance after 1979. Except for Japan, this increase in the variance occurs in other countries, although with different timing and smaller magnitude. In all these countries, however, the estimated variance decreases substantially in 1983 .

This suggests that increases in the variance of return may account for part of the increase in long real rates in five of the six countries, but two

34. Estimates from Frankel, "Portfolio Crowding-out,"'imply that a 1 percent increase in public debt raises the risk premium on pulic debt by less than 1 basis point.

35. Z. Bodie, A. Kane, and R. McDonald, "Why are Real Interest Rates So High?" (Boston University, School of Management, April 1983). 
Figure 4. Rolling Variance of Real Holding Returns on Bonds, 1973-84
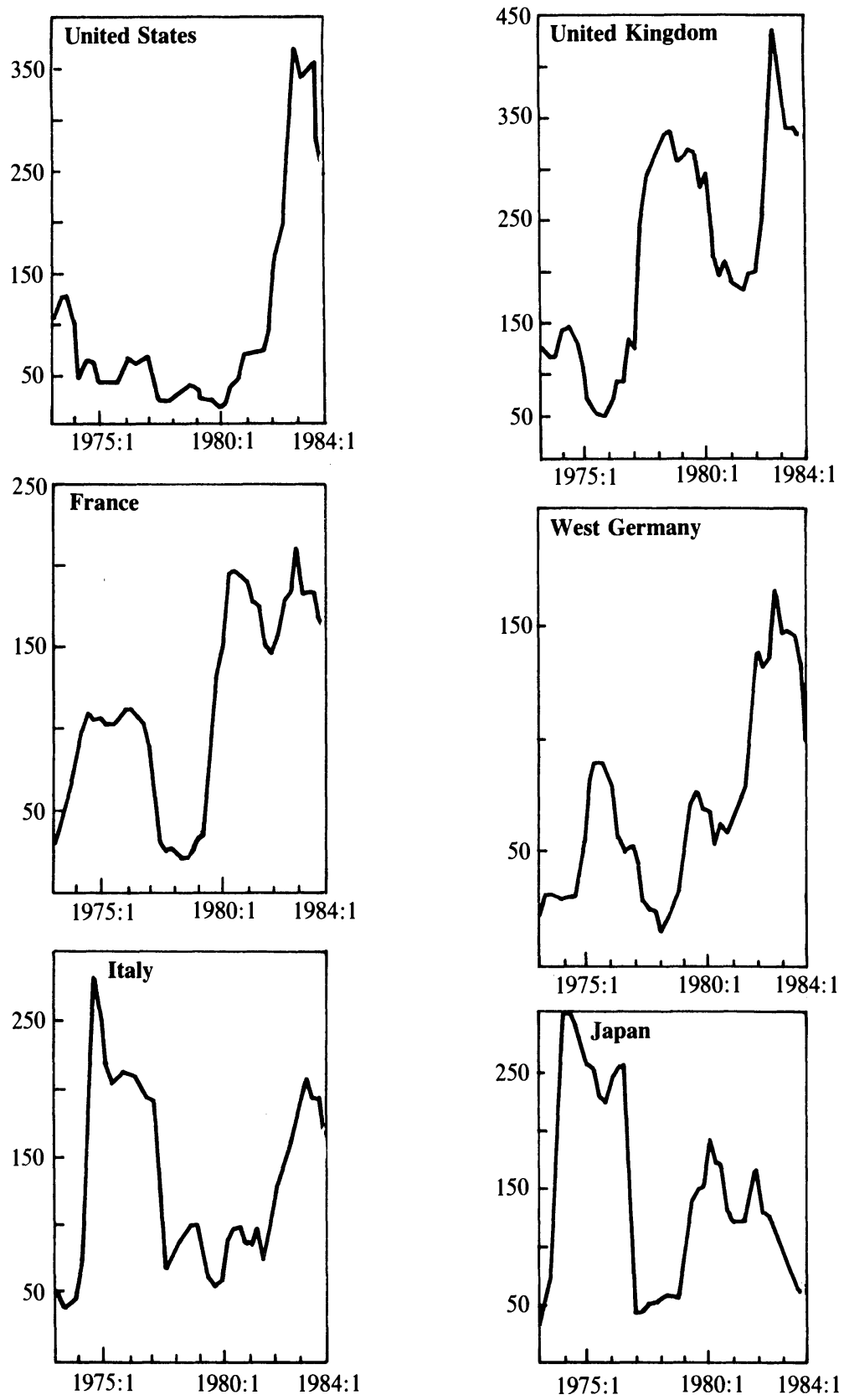

Source: Same as in figure 1.

a. Rates of return are in percent at annual rates and deflated by the domestic CPI. 
caveats are in order. First, there is an important distinction between one-period required rates of return and long-term bond yields. The yield on a bond is the average of the current one-period rate and of one-period rates of return expected to prevail over the life of the bond. Even if the variance of rates of return on long bonds is expected to remain constant in the future, the one-period rate of return on any finite maturity instrument would be expected to fall as it approached maturity. Thus the yield would increase by far less than the estimated one-period risk premium increase given by Bodie, Kane, and McDonald. Furthermore, there is no reason for market participants to assume that any increase in variance is permanent. Indeed, time series evidence on the movement of the variance suggests that variance is only weakly serially correlated. Therefore, if market participants expect the variance to return to a "normal" level in the future, the risk premium in yields on long-term bonds may be substantially smaller than the estimate of Bodie, Kane, and McDonald. ${ }^{36}$

The second caveat is at least as important as the first. It is that the one-period capital asset pricing model may be misleading in evaluating the risk associated with holding bonds. In the absence of inflation risk, long-term bonds allow portfolio holders to avoid the risk associated with rolling over short maturity bonds: their return at maturity is fixed in terms of consumption. Thus an increase in the variance of rates and thus in the variance of the one-period rate of return on long bonds does not necessarily imply higher risk on long bonds. ${ }^{37}$ If, however, the variance of rates of return on bonds comes from inflation variance, long bonds then are truly more risky and will require a higher risk premium.

An alternative explanation for both high real rates and the strong

36. This is discussed in more detail in "The Persistence of Volatility and Stock Market Fluctuations," by J. Poterba and L. Summers (Massachusetts Institute of Technology, September 1984). This paper finds litle persistence in stock volatility. Work in progress suggests similar conclusions for bonds.

37. Although holding bonds of maturity $N$ guarantees one unit of consumption at time $N$, rolling over of shorter maturity bonds may sometimes be a better strategy. This would be the case if the rollover strategy tends to do unexpectedly well when consumption is unexpectedly low at time $N$; in this case the rollover strategy provides a better hedge. There will then be a positive premium required to hold long bonds. John Y. Campbell, "Risk Premiums on Stocks and Real Bonds in a Simple Exchange Model" (Princeton University, August 1984), presents a simple analysis of risk premiums in a multiperiod model. 
performance of the stock market was proposed by Modigliani and Cohn to explain the poor performance of the stock market in the $1970 \mathrm{~s} .{ }^{38}$ The authors suggest that financial markets exhibit inflation illusion, a confusion of the distinction between nominal and real returns. As a consequence, markets compare dividend or earning yields on stock with nominal rather than real interest rates. On this view, a period of declining inflation would witness rising real interest rates and stock prices but falling nominal rates. This corresponds roughly to what has been observed. The inflation illusion hypothesis is also consistent with a general failure of rates to fully adjust to taxes and inflation ${ }^{39}$ and the poor performance around the world of equities as an inflation hedge. Note that the level of long-term nominal interest rates in most countries peaked in 1982, just before the major stock market rallies began. This is precisely what the inflation illusion hypothesis would predict. The inflation illusion view also explains the high current level of real interest rates by suggesting that real rates throughout the 1970s were artificially depressed by inflation. Had economic decisionmakers understood the effects of inflation, nominal rates would have been even higher.

Although inflation illusion can rationalize actual developments, it has problems as a working hypothesis. Most obviously, if stock market investors were fooled by inflation during the 1970s, why were investors in residential real estate not fooled? Average citizens should, on the inflation illusion view, have overestimated mortgage burdens and underestimated the value of the residential housing stock. Finally, microeconomic evidence on the inflation illusion hypothesis is rather mixed. ${ }^{40}$ Thus despite its ability to explain recent movements in asset returns, we are still reluctant to accept it.

Overall, we see the empirical evidence on portfolio shifts as mostly inconclusive. However, portfolio shifts and changes in risk premiums are always difficult to identify, and some of the evidence on the variances of bond returns and on the inflation illusion hypothesis can be interpreted as providing some support for the portfolio-shift explanation.

38. Franco Modigliani and Richard A. Cohn, "Inflation, Rational Valuation, and the Market," Financial Analysts Journal, vol. 35 (March-April 1979), pp. 24-44.

39. See Summers, "The Non-Adjustment of Nominal Interest Rates."

40. See Lawrence Summers, "Inflation and the Valuation of Corporate Equities," Working Paper 824 (National Bureau of Economic Research, December 1981). 


\section{Summary}

We started by reviewing the behavior of asset prices and returns since 1978. Our main conclusion was that, although short-term, medium-term, and probably long-term real rates had substantially increased, required rates of return on stocks had apparently not followed; the stock markets had been surprisingly strong. We then identified four factors that could in theory account for the high real interest rates: adverse shifts in saving, favorable shifts in profitability, tight money, and portfolio shifts. We found that they had different theoretical implications for the behavior of stock prices. In particular, adverse shifts in saving or tight money could not explain the strong stock market, whereas profitability increases or portfolio shifts, through changes in risk premiums, could.

We then turned to an empirical examination of the potential role of each of these four factors. Starting with fiscal policy, we found no evidence in favor of the thesis that deficits are leading to low saving: in the OECD as a whole, there has been little change in structural public dissaving and there is no reason to think that the future will be any different. As for a shift in profitability, although it is difficult to pinpoint the origins of such shifts, the strong behavior of investment in the face of high real rates suggests that one has taken place. Turning to tight money, we found no reason to doubt that tight money is responsible for the initial increase in real rates, approximately from 1978 to 1982 . For the post-1982 period, two fiscal-monetary mix explanations are plausible: tight European money used to counteract the dollar appreciation coming from the divergence in fiscal policies in the United States and elsewhere, or tight anticipated money as the U.S. economy nears full employment. Last, we looked at the potential role of portfolio shifts; although we found little evidence in their favor, it is difficult to identify such portfolio effects, and the evidence can be interpreted as inconclusive rather than negative.

This analysis leads us to the following conclusions. High real rates are not due to fiscal policy alone. They are probably partly due to a fiscal-monetary mix, and smaller U.S. deficits would, other things equal, bring down interest rates. Interest rates would, therefore, decline either if Europe accepted further depreciation or if the U.S. recovery slowed down so that U.S. monetary policy was not anticipated to tighten further. 
Underlying these developments and explaining the performance both of stock markets and of investment is a shift in profitability. This suggests that, were the other factors to disappear, real rates would probably remain higher than in the 1970 s.

\section{APPENDIX}

\section{A Measure of Fiscal Stance}

As WE NOTED in the text, measuring the impact of fiscal policy on aggregate demand merely by looking at current deficits is only a rough first approximation. Quite apart from the varying effects of different taxes or spending programs, perceptions of future deficits must also affect aggregate demand. We derive here a more attractive measure and construct its empirical counterparts for the countries considered in this paper.

Let $G$ be government spending on goods and services, $T$ taxes, and $B$ debt. The deficit is therefore $r B+G-T$, where $r$ is the real interest rate and the primary deficit, $D$, is equal to $G-T$. Fiscal policy affects aggregate demand both directly through $G$ and indirectly through consumption, which depends on taxes and debt; thus, to characterize its effect, we must specify consumption behavior. ${ }^{41}$ We postulate a standard life-cycle consumption function relating consumption to wealth, both human and financial:

$$
C=\lambda[K+B+\Pi(W-T ; r+p)],
$$

where $C$ is consumption, $\lambda$ is the marginal propensity to consume out of wealth, $K$ is the capital stock, so that $K+B$ is nonhuman wealth, and $W$ is labor income, so that $W-T$ is after-tax labor income. Notation of the form $\Pi(a ; b)$ denotes the present value of a stream $a$ discounted at rate $b$. Thus $\Pi(W-T ; r+p)$ is the present value of after-tax labor

41. This makes clear that any measure of fiscal stance depends implicitly or explicitly on a specification of consumption behavior and is therefore theory specific. This point has been made by Alan S. Blinder and Robert M. Solow, in The Economics of Public Finance (Brookings, 1974), and suggests the construction of a set of alternative measures. 
income, discounted not at rate $r$ but at rate $r+p$. We may think of $p$ as a myopia coefficient, reflecting the mortality of current consumers or their systematic myopia about the future; it will play an important role in what follows. This way of introducing myopia is by no means the only one. Consumers may discount labor income and taxes at different rates; they may have static expectations of future taxes but be more sophisticated in forming expectations of future labor income. We think, however, that our specification captures an essential element, namely myopia about the future. Finally, in order to focus on implications of forwardlooking behavior, we ignore liquidity constraints. ${ }^{42}$

Collecting terms in aggregate demand that depend directly on fiscal policy gives

$$
X \equiv \lambda[B-\Pi(T ; r+p)]+G .
$$

Adding and subtracting the present value of government spending discounted at rate $r+p$ gives

$$
X=\lambda[B+\Pi(D ; r+p)]+[G-\lambda \Pi(G ; r+p)] .
$$

Equation 12 provides a basis for thinking about the effects of a fiscal program on aggregate demand. Before we do so, we note that the choices of $B, G$, and $T$ (equivalently $D$ ) by the government are not independent. The dynamic budget constraint faced by the government is:

$$
\mathrm{d} D / \mathrm{d} t=r D+G-T .
$$

If we assume that the government does not intend to let its debt grow forever faster than the rate of interest, the government is then constrained by an intertemporal budget constraint:

$$
B+\Pi(D ; r)=0 .
$$

A positive level of debt must be offset by prospective primary surpluses in the future..$^{43}$ Debt must be equal to the present value of future primary surpluses, discounted at the market interest rate $r$. We

42. The consumption function of equation 10 is formally derived in Olivier J. Blanchard, “Debt, Deficits and Finite Horizons," Journal of Political Economy, forthcoming. The extension to the case where some consumers are liquidity constrained is given in Willem Buiter, "Measuring Aspects of Fiscal and Financial Policy," paper prepared for the February 1984 ISPE conference on public debt.

43. Note that the measure of fiscal policy derived above does not depend on whether equation 13 is satisfied. 
now return to equation 12 . The first term represents the effects of government finance. If spending is always financed by concurrent taxes, then it is identically equal to zero; if consumers are not myopic, that is, if $p$ is zero and the fiscal program satisfies the intertemporal constraint of equation 13, then the government finance term is still zero:

$$
B+\Pi(D ; r+p)=B+\Pi(D ; r)=0 .
$$

This is the well-known "Ricardian equivalence" proposition. If consumers discount future taxes at the interest rate, the timing of finance is irrelevant; all that matters is the path of spending. If, however, as is likely, $p$ is positive, the finance term is not zero. In particular a sequence of large anticipated deficits will increase this term and increase aggregate demand. Although consumers recognize that taxes will be raised eventually, it is far enough in the future that it does not affect their consumption very much. This first term makes clear that both the level of debt and the sequence of anticipated deficits affect aggregate demand.

The second term of equation 12 characterizes the effects of government spending if financed by concurrent taxes. The level of spending has an ambiguous effect on aggregate demand; the sign of the effect depends on the specific values of $\lambda, p$, and interest rates. The path of spending also affects aggregate demand. A prospective increase in spending if financed by concurrent taxes implies higher prospective taxes. Consumers anticipate these higher taxes and reduce their consumption. Therefore the effect of a prospective increase in spending is contractionary and that of a prospective decrease expansionary.

\section{Empirical Implementation}

In constructing an empirical counterpart to $X$, we focus only on the first term of equation 12, the finance component. We do this because of the conceptual problems associated with the choice of the empirical counterpart to $G$ and because of the lack of reliable forecasts of $G$.

Our first step is to divide $X, B$, and $D$ by GNP. Denoting ratios of these variables to GNP by lowercase letters gives

$$
x=\lambda[b+\Pi(d ; r+p-g)] .
$$

The coefficient $g$ is the rate of growth of GNP. We then assume $r, p$, and 
$g$ to be constant through time; this is simpler than to allow them to vary and does not affect the time path of the index substantially. Last, we assume that $r+p-g$ is equal to 10 percent per year. Choosing a different value, say 6 percent, affects the level of the index but has little effect on its time path. ${ }^{44}$ The empirical index is thus

$$
x_{t}=\lambda\left(b_{t}+\sum_{i=0}^{\infty}(1.1)^{-i} d_{t, t+i}\right),
$$

where $d_{t, t+i}$ is the forecast of the ratio of the primary deficit to GNP in year $t+i$, as of time $t$.

\section{The U.S. Fiscal Index}

We construct the U.S. fiscal index as follows. For the years 1978 to 1984 we use for $b_{t}$ general government net financial liabilities as a percent of GDP. ${ }^{45}$ For each year $t$, we use DRI's midyear $t$ forecasts of ratios of primary deficits to GNP for years $t$ to $t+11$. Primary deficits are the sum of federal, state, and local government deficits as defined in the national income accounts, minus the sum of federal, state, and local government net interest payments. Ratios of deficits to GNP for years $t+i, i>11$, are assumed equal to the forecast for year $t+11$. (The relative weight of the first twelve years is 65 percent.)

We also construct forecasts, as of mid-1984, of future values of the fiscal index for the years 1985 to 1990 . To construct the year $t$ forecast, we use mid-1984 DRI forecasts of ratios of primary deficits to GNP for years $t$ to $t+11$. We construct forecasts of $b_{t}$ by using the identity

$$
b_{t+1}=\left(1+r_{t}-g_{t}\right) b_{t}-d_{t} .
$$

To construct forecasts of $b_{t}$ for the years 1984 to 1989 we use for $d_{t}$ the DRI forecasts of ratios of primary deficits to GNP and for $g_{t}$ the DRI forecasts of real output growth. Because part of government debt does not bear interest, the average interest real rate $r_{t}$ on government debt is lower than the market real rate. We compute $r_{t}$ as the ratio of OECD

44. The value of 10 percent is based on Hayashi's estimates of the consumption function specified in equation 10. His estimates (no liquidity constraints) imply, at annual rates, $p=0.10, r=0.03$ (Fumio Hayashi, "The Permanent Income Hypothesis").

45. OECD, "Structural Budget Deficits and Fiscal Stance." 
forecasts of real interest payments on government debt for 1985 divided by OECD forecasts of beginning-of-year 1985 debt. ${ }^{46}$ This gives a value for $r$ of 4.4 percent. We assume $r_{t}$ equals this value for all years 1984 to 1989; this allows us to construct a series of forecasts for $b$ and the fiscal index. Table A-1 presents the results for the United States (as well as for Europe, Japan, and the six-country aggregate, the calculations for which are discussed below). The results suggest a steady increase in the U.S. fiscal index from 1979 to 1983, followed by a slow decrease from 1984 onward. As we already discussed in the text, it is important to note that the movement from 1983 to 1984 is due to the relative optimism of the mid-1984 DRI forecasts. If we used 1984 CBO baseline projections instead, the value of the index would not decline by as much after 1983 . It would show values of $\Pi(d)$ for 1984 and following years approximately equal to those of 1983 .

As it is, the index shows a major fiscal expansion from 1979 to 1983, with a particularly large increase in 1983 . The year 1983 is the only one for which the present value of primary deficits is positive. The index decreases in 1984 and stabilizes at a high level. If we assume that the marginal propensity to consume out of wealth, $\lambda$, is equal to 0.1 , then the U.S. fiscal index column of table 13 suggests that the change in fiscal program from 1979 to 1984 had a direct impact on aggregate demand of 1.8 percent. Of this, 0.4 percent was due to the buildup in debt and the rest to anticipations of larger deficits.

\section{Fiscal Indexes for Europe and Japan}

Medium-term and long-term forecasts of future primary deficits are not available on a consistent basis for the period 1978-84 for countries other than the United States. (One-year-ahead forecasts of deficits are available from the OECD.) This forces us to take a different approach. For each of the European countries, for each year $t$, we form forecasts of deficits by using $d_{t, t+i}=d_{t}+\alpha\left(u_{t, t+i}-u_{t}\right)$, where $t=1978$ to 1984 .

The variable $d_{t}$ is the ratio of the general government primary deficit to GNP for 1978 to $1984 .{ }^{47}$ The variable $u_{t, t+i}$ is the midyear $t$ DRI forecast

46. OECD Economic Outlook, July 1984.

47. For 1978-83, from OECD, "Structural Budget Deficits," and for 1984, from OECD Economic Outlook, July 1984. 


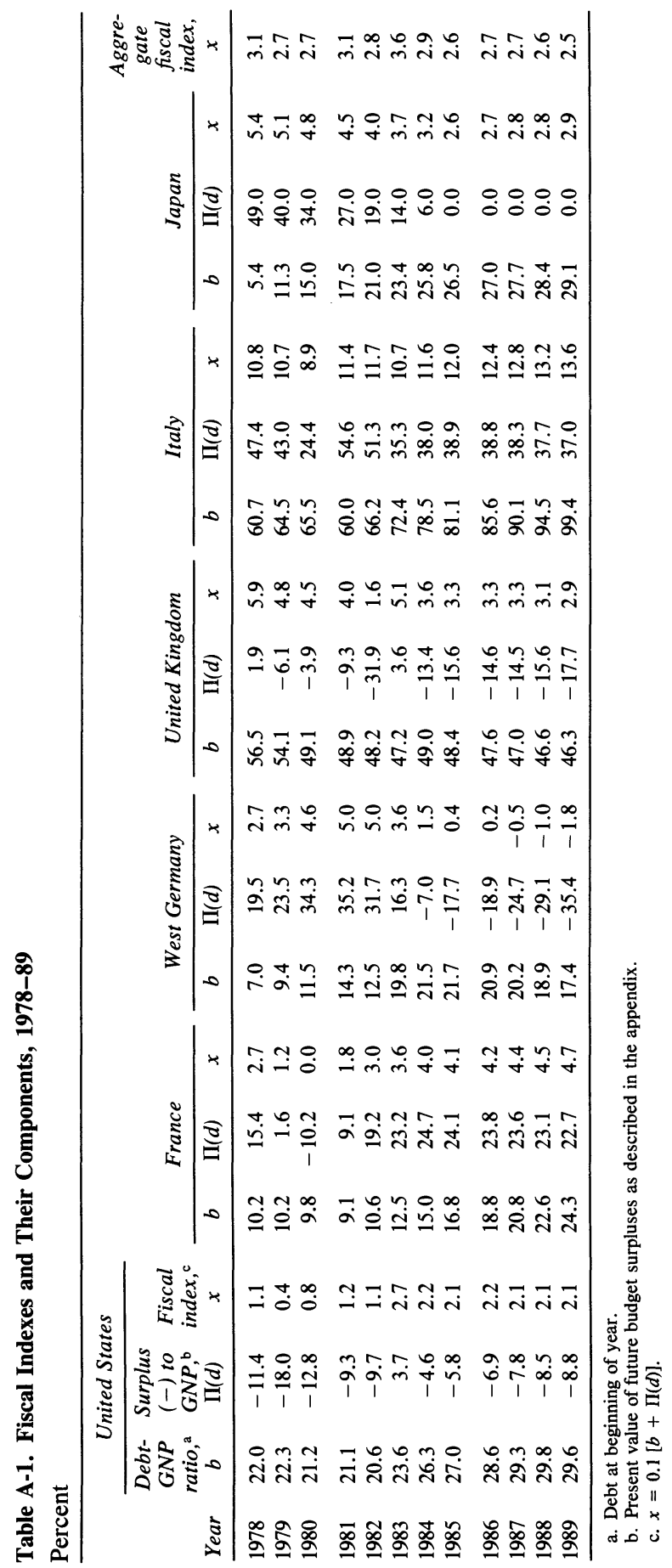


of the unemployment rate for year $t+i$. The coefficient $\alpha$ captures the effect of the level of economic activity on $d_{t}$ : if unemployment increases by 1 percent, the ratio of primary deficit to GNP increases by $\alpha$ percent. We choose $\alpha$ to be 0.7 for the United Kingdom and West Germany, and 1.0 for France and Italy; these values are consistent with standard cyclical adjustments for these countries. We also construct forecasts of the fiscal index, for each country, for $t=1985$ to 1989 . To do so we use the following formula for the mid-1984 forecasts of $d_{t+i}$ :

$$
d_{84, t+i}=d_{84,85}+\alpha\left(u_{84, t+i}-u_{84,85}\right) .
$$

Values of 1984 forecasts of primary deficits and of unemployment for 1985 are obtained from the OECD Economic Outlook, July 1984. Values of $u_{84, t+i}$ are mid-1984 DRI forecasts. Values of $b_{t}$ for 1978 to 1984 are obtained from OECD, "Structural Budget Deficits." Forecasts of $b_{t}$ for 1985 to 1990 are constructed in the same way as for the United States, using mid-1984 DRI forecasts of growth; real interest rates are also constructed as they were for the United States. The real interest rates so constructed are equal to 3.0 percent for France, 4.1 percent for Germany, 4.1 percent for the United Kingdom, and 3.7 percent for Italy.

This description makes clear that the constructed indexes for Europe do not take into account anticipated structural changes in primary deficits but only changes due to anticipated movements in output. The index for France decreases from 1978 to 1980; the increase from 1980 to 1983 corresponds to the socialist fiscal expansion of 1981-82; the index is anticipated to increase slightly from 1983 onward, due to the buildup of debt. The index for West Germany shows steady contraction from 1981 onward. The index for the United Kingdom shows a large contraction from 1978 to 1982, fiscal expansion in 1983, and anticipated contraction for the future. The index for Italy shows a steady increase, the net result of decreasing anticipated deficits and steadily increasing debt.

Medium-term and long-term forecasts of primary deficits or GNP are not available on a consistent basis from 1978 for Japan. Thus our index for Japan is constructed in a very crude way. We assume that the ratio of the primary deficit to GNP is always expected to be constant. Values of $b_{t}$ and $d_{t}$ for years 1978 to 1984 are obtained from the OECD's "Structural Budget Deficits." Values of $b_{t}$ for 1985 to 1990 are obtained in the same way as for the United States, using mid-1984 DRI forecasts of GNP growth. The real interest rate on government debt is taken to be 
4.2 percent. The results show steady fiscal contraction since 1978; the increase in debt is more than offset by the sharp decrease in anticipated deficits.

Last, we construct the fiscal index for the group of countries as a whole (the last column of table A-1); for 1978-83 we use contemporaneous exchange rates and thereafter 1983 exchange rates and GNP. Except for 1983, the overall index shows little movement, confirming the conclusion obtained using the text's cruder structural deficit measures. 


\section{Comments and Discussion}

Alan S. Blinder: Three nights ago at a cocktail party in Paris, two local journalists approached me-I was virtually the only macroeconomist at the conference-to ask the question that all journalists seem to ask these days: why are real interest rates so high, and to what extent is the U.S. budget deficit to blame?

I gave them what I took to be the standard response of mainstream economists: real rates are high because of unrelentingly tight money in the United States since 1979 (except for a brief hiatus in the last six months of 1982), which, among other things, has forced many European countries into tight money in order to defend their currency values. Since 1982, tight money has been coupled with a large fiscal stimulus from President Reagan's program, a stimulus that has grown larger over time. High real interest rates are exactly what one expects from such a policy mix.

If pressed further, I would have added something about higher risk premiums in long-term bond rates and something about financial deregulation in the United States. But I was not. Being tired and under the influence of champagne, it did not occur to me to mention either the end of OPEC's surplus or the worldwide investment boom. But perhaps I should have.

I certainly did not think, either then or now, that there was anything original in my response. Rather, I thought myself to be reciting the canonical answer. In this thoughtful and thought-provoking paper, Olivier Blanchard and Lawrence Summers claim that there are a few problems with this standard story.

First, since money is presumably neutral in the long run, high real short rates caused by tight money ought to be accompanied by a 
descending real yield curve. Yet real long rates appear to be higher than real short rates.

Second, stock markets have boomed throughout the world since 1982, which is not what we expect to happen when money is tight.

Third, the U.S. fiscal expansion was largely offset by fiscal contractions in other OECD countries, leaving little if any net world fiscal expansion.

Each of these developments appears to be at variance with the standard story. Yet, by the end of the paper, Blanchard and Summers seem to have more or less agreed with what I told the French journalists. Let me take each of the problems in turn.

Not even two economists as ingenious as Blanchard and Summers know what the term structure of real interest rates is-except (as they point out) in the United Kingdom. Since we can make better estimates of real short rates than of real long rates, most economists pay more attention to the former even though the latter are arguably more important for economic activity.

Blanchard and Summers's numbers illustrate just how hard it is to pin down even real short rates. Look at the table below, which is constructed from numbers in Blanchard and Summers's tables 1 and 2. It gives the estimated changes in real short interest rates over two different intervals according to the two different estimation methods they use. From 1978 to 1984 , which is the period on which they focus, the real short rate in the United Kingdom went up by either 8.2 points or 2.3 points depending on how you measure it. Between 1980 and 1983, which for reasons to be explained later is the period I prefer, the real short rate in West Germany

$\begin{array}{ccccccr} & \begin{array}{c}\text { United } \\ \text { States }\end{array} & \text { France } & \begin{array}{c}\text { West } \\ \text { Germany }\end{array} & \begin{array}{c}\text { United } \\ \text { Kingdom }\end{array} & \text { Italy } & \text { Japan } \\ \begin{array}{c}\text { Changes, 1978-84 } \\ \begin{array}{c}\text { With DRI forecast } \\ \text { for inflation }\end{array}\end{array} & 4.9 & 6.1 & 5.8 & 8.2 & 2.6 & 7.2 \\ \begin{array}{c}\text { With statistical } \\ \text { forecast for } \\ \text { inflation }\end{array} & 4.3 & 4.3 & 1.8 & 2.3 & 5.9 & 9.6 \\ \begin{array}{c}\text { Changes, 1980-83 } \\ \text { With DRI forecast } \\ \text { for inflation }\end{array} & 2.9 & 0.4 & 1.9 & 4.4 & 6.1 & 3.5 \\ \begin{array}{c}\text { With statistical } \\ \text { forecast for }\end{array} & 4.3 & 4.2 & -1.8 & 1.4 & 3.2 & -0.5\end{array}$


either rose 1.9 points or fell 1.8 points! Such examples could be multiplied.

The conclusion is obvious: the margin of uncertainty in deciding what has happened even to real short rates is enormous. How much larger, therefore, must our margin of error be in estimating real long rates?

For Britain, Blanchard and Summers offer us direct measurements of real long rates, which we can compare with their estimates. For 1982, their estimate of the five-year real rate is 0.6 percent using statistical forecasts of inflation (table 3) or 5.3 percent using DRI's forecasts (table 4). That is quite a discrepancy, which simply reiterates the previous point. Since the corresponding estimated short rates are 1.5 percent and 4.2 percent, their estimated yield curve is either ascending or descending, depending on the measurement technique! Which answer is right? We can see in their table 5 that the true observed real rate on a six-year indexed bond at the time was 2.9 percent or 2.7 percent. But to which short rate (1.5 percent or 4.2 percent) should it be compared?

My point here is not to criticize Blanchard and Summers's procedures; mine wouldn't be any better. My point is that inferring the slope of the term structure of real interest rates is a hazardous and probably impossible enterprise in the absence of indexed bonds. In the one case for which we have genuine data, Britain in 1981-84, table 5 clearly shows a mostly descending yield curve most of the time.

Furthermore, as Blanchard and Summers correctly state, the horizon over which money should not affect real interest rates is long relative to the weighted average of expected returns that is embodied in five-toseven year bond rates. In the British case, table 5 shows that the rise in real rates was far smaller at truly long maturities than at medium maturities.

So it seems to me that Blanchard and Summers have little basis for claiming that the real yield curve sloped the "wrong" way. The interest rate data give little reason to question the tight money explanation.

After listening to Robert Shiller's paper earlier at this conference, one might legitimately wonder why we should spend any time worrying about the behavior of stock market prices in this context. But Blanchard and Summers do, so let me address their question directly: if tight money and large deficits caused high real long rates, why would the stock market boom?

Let's first review what actually happened to the U.S. stock market and decide exactly what is puzzling. The stock market plummeted in 
1981 and into 1982 despite the election of the most capitalist-intensive president since Coolidge-even though the new president set about to cut every tax on capital that he could think of. That does seem puzzlinguntil you realize that Wall Street was worried sick about the current and impending budget deficits.

Then the stock market staged the strong rally that Blanchard and Summers focus upon. But note that this rally took place (1) right after passage of a major deficit-reduction bill, (2) just as the Federal Reserve was loosening up on money and allowing interest rates to fall dramatically, and (3) in anticipation of a cyclical recovery. This is unusual behavior?

Now, it may well be, as Blanchard and Summers claim, that the stock market boom was too large to be explained by the events I have just mentioned. And it certainly was too large to be explained by improved dividend prospects. But what's new about that? The stock market overreacts to anything and everything. Why should the 1982-83 boom have been different?

In addition, it is worth noting that the market tumbled again from mid1983 to mid-1984 - an episode Blanchard and Summers ignore and that somehow does not even show up on their chart. Between July 1983 and July 1984, the real New York Stock Exchange composite average (deflated by the CPI) declined 13.6 percent, bringing it almost back to its 1978 level.

So, taking the 1981-84 period as a whole, it is far from clear that there is anything in stock market behavior that strongly contradicts the standard story.

Besides, as Blanchard and Summers mention at the end of their paper, the Modigliani-Cohn hypothesis of inflation illusion provides a perfectly coherent explanation of just about every major movement of the stock market in the past dozen years-and of other phenomena as well. This is no mean achievement! It is true that the inflation illusion hypothesis does not explain why home buyers failed to overestimate the real rates implied by high nominal mortgage interest rates in the 1970s. But it does seem to me that Blanchard and Summers dismiss a rather promising explanation much too cavalierly.

In table 10, Blanchard and Summers contrast the change in the fiscal posture of the United States (first column) with that of the "world" as a whole (last column). After adjustment for stage of the business cycle and for inflation accounting, the United States shifted from a surplus of 
0.5 percent of GNP in 1978 to a deficit of 1.3 percent of GNP in 1984an expansionary change of 1.8 percent of GNP. But for the seven-country "world," the corresponding shift was a decline in the deficit from 1.6 percent to only 0.8 percent of GNP-a contractionary change of 0.8 percent of GNP. So Blanchard and Summers conclude that there was no fiscal stimulus in the world as a whole and, hence, that budget deficits can hardly account for high interest rates.

I dispute this conclusion for at least two important reasons. First, if we treat the OPEC surplus in parallel with budget positions in the industrial countries, the picture changes considerably. The "world" deficit starting from the time of the second OPEC oil shock now changes from a surplus of 1.2 percent of GNP in 1979-80 to a deficit of 1.2 percent of GNP in 1983-84.

Second, the "fiscal expansion" part of the standard story probably does not start before 1981 and certainly not before 1980 . No one has claimed that the huge budget "deficits" of the Carter years (which were surpluses on a high-employment, inflation-adjusted basis) drove up real interest rates. If we change the comparison period from 1978-84 (Blanchard and Summers's choice) to $1980-83$, U.S. fiscal policy moved toward deficit by 2.3 percent of GNP (from +1.1 to -1.2 ) and world fiscal policy moved toward deficit by 1.2 percent of GNP (from +0.1 to -1.1). Since the U.S. economy constitutes roughly half of this "world," these numbers imply that there was no offset to expansionary U.S. fiscal policy coming from Europe and Japan during the 1980-83 period.

This conclusion could hardly be more different from the one drawn by Blanchard and Summers. To me, the data on fiscal deficits actually support the standard story rather than undermine it.

Blanchard and Summers worry too much. It is true that the standard story has some loose ends, which they point out honestly, skillfully, and perceptively. I learned a good deal by reading the paper. But taken as a whole, their exhaustive and excellent tour of the theoretical arguments and empirical evidence mainly supports the standard story. It really does look as though a policy mix of tight money (especially early) and loose fiscal policy (especially late, and in the future) pushed world real rates up and kept them there.

Blanchard and Summers's list of nagging worries is more nagging than worrisome. Over the relevant period, fiscal policy certainly was expansionary. And the term structure of interest rates does not point the finger of guilt away from tight money. It is true that the behavior of stock prices 
is harder to explain. But they probably should leave that to Modigliani and Cohn-maybe even to Shiller.

William D. Nordhaus: The last half-dozen years have been very puzzling for observers of financial markets. One of the puzzles, which has been responsible for more than its share of spilt ink, is the rise in real interest rates since 1979.

Among mainstream macroeconomists, the canonical explanation probably runs as follows. A combination of external and internal events left the United States in 1979 with intolerably high inflation and a gradual updrift in the size of the structural budget deficit relative to GNP. In October 1979 the Federal Reserve grasped the nettle of a monetariststyle disinflation. Nominal and real interest rates rose and the dollar skyrocketed as the economy was driven into a deep recession. We might have expected real interest rates to fall as inflation was routed. They did not, in the canonical view, because loose fiscal policy led to a higher equilibrium level of real interest rates.

The paper by Blanchard and Summers does not really dispute this canonical mainstream interpretation. Rather, they amplify and flesh it out; point out some puzzles unexplained by it; and poke holes in several competing explanations. Overall the paper is a thorough and balanced analysis of the high-real-rate puzzle.

Among other puzzles, three are noteworthy. First, one of the lines of argument of many analysts (including the Feldstein-Mondale school) is that the high real interest rates are caused by high future deficits. Blanchard and Summers argue that, from a global perspective, the presumption behind this argument is questionable. In a world of highly mobile funds, interest rates should be determined by global monetary and fiscal policy. Global fiscal policy has been either neutral or mildly expansionary over the period since 1978 . If we look at the period when real interest rates were rising, however, from 1980 on, fiscal policy was indeed expansionary. The issue is whether the small degree of expansionary impulse from fiscal policy could have been responsible for the rise in real rates. This is still an open question.

Second, Blanchard and Summers point out that the canonical story has several difficulties in explaining the timing of real interest rate movements and particularly why high rates lasted so long. In the end they seem to lean toward a two-part explanation, which I will tease out 
a bit. From 1979 to 1982 was a period of "disinflationary monetarism," in which real interest rates were high as the Federal Reserve tightened money to drive down inflation. Since 1982, however, a different force has been at work-one that might be called "preemptive monetarism." During this period, the Federal Reserve has been forced to keep real interest rates high to preempt the actual or prospective effects of the stimulative U.S. fiscal policy. In part, the Federal Reserve seems to have been threatening the Congress with the prospect that real interest rates would stay high until the deficit was reduced; to some extent, particularly during 1983 and 1984, real interest rates were high because, given the high fiscal deficit, the Federal Reserve's unemployment and inflation targets could be met only with relatively high real interest rates. As long as the Federal Reserve is pursuing ultimate targets that are affected by fiscal policy - targets such as prices, output, and unemployment-a fiscal expansion will raise real interest rates as the Federal Reserve reacts, choking off interest-sensitive demands to offset the fiscal stimulus.

Another piece of information about the source of the high real interest rates lies in the term structure of interest rates. Say we start with a flat term structure. A strategy of disinflationary monetarism should have led to a declining term structure (indeed future implicit nominal short rates should decline). This appears to have occurred in 1979-81. Preemptive monetarism, however, would lead to a flat or rising yield curve depending on the timing of fiscal expansion. There is some evidence of an upward tilt in the term structure after 1981.

One place where the authors' argument misses the mark concerns the risk premium on long-term bonds. Before 1979 the one-month holding returns on long bonds were virtually independent of holding returns on other assets. Since 1979, long bonds appear to have assumed about as much short-term market risk as stocks. If we put any faith in a capital asset pricing model (CAPM), then after 1979 we should see a substantial risk premium of perhaps 200 or 300 basis points on long bonds. Blanchard and Summers use a consumption CAPM to discredit such a thought. This is not an informative test, because the consumption CAPM has been shown to be a useless model for predicting the risk premia on assets like common stocks. Only time will tell, but I believe that we will see a substantial term premium on long-term bonds as long as they have the risk characteristics shown since 1979. 
But the heart of the Blanchard and Summers paper concerns the puzzle of surging stock markets. Clearly, a monetary disinflation should be a triple whammy on real stock prices-it would lower profits by lowering aggregate demand, raise the discount rate through the interest rate effect, and further lower stock prices as the high dollar reduces the profitability of domestic corporations. But real stock prices have not fallen since October 1979. What was at work here?

Blanchard and Summers propose a "brave new world" explanation. They argue that expected profits rose more than enough to offset the rise in real interest rates. What forces might have been at work? We have seen the lowering of capital taxes, the turn to the right in economic policy, dissipation of the Carter malaise, routing of the last vestige of Mitterrand's Keynesiosocialism, less uncertainty about the future, a tough stand against unions (like the air controllers), perhaps even some residual jingoism from imperialist wars in the Falklands and Grenadathese notches in the blazing guns of laissez faire heartened the bulls and routed the bears. $\mathrm{O}$ brave new world of supply-side capitalism that has such wondrous animal spirits in it! Thus spake Blanchard and Summers.

How seriously should we take this brave-new-world view? It is surely ingenious, but the evidence is pretty thin. The first issue is the signal-tonoise problem. Stock prices are notoriously badly behaved. Should we interpret the stability of stock markets since 1979 as a measure of rational forward-looking investors, as Blanchard and Summers would tell the story? Or as a herd of investors whose mood inexplicably turned bullish over the last half decade, as Robert Shiller's paper in this issue might persuade us? A glance at Shiller's figure 1 does not indicate that, in a historical perspective, the last few years have produced an extraordinary bull market. In short, given the volatility of stock markets, we should give but a small weight to anomalous stock market movements when other features of a theory appear to fit the facts.

Second, there is the expected-signal problem. Many people feel that the stock market was significantly undervalued in 1979-as was indicated by a ratio of market value to replacement cost of corporations of 0.7 . If the stock market was indeed undervalued, then the increase in real rates was battling (weak) market forces tending to correct the undervaluation.

Third, the timing of stock market movements does not match the theory. U.S. stock prices went up from 1979 to November 1980, a period 
in which real interest rates were almost constant. But after the $\mathbf{1 9 8 0}$ Reagan election stock prices fell about 30 percent in real terms as the supply-side program was proposed, marketed, passed, and analyzed. Stock prices continued to fall till summer 1982, when the Federal Reserve reversed its monetarist operating policies and eased money. Stock and bond prices rose sharply starting in summer 1982 as expected future interest rates fell. In sum, there simply was no surge of stock prices during the period when markets were absorbing the supply-side policies.

Lastly, the fundamental hypothesis of an upturn in expected profits is unsupported by any evidence on expected profits. One can, however, examine long-term profit forecasts of groups like DRI to see whether there is evidence of the posited upturn and whether changes in forecast profits appear to explain stock-market movements.

In general, DRI's profit forecasts do not move in line with the story told by Blanchard and Summers, nor do they move with stock prices. Deflated profits after taxes as forecast by DRI for 1985 (call these " 1985 profits") are virtually constant during the stock market increase from 1978 to the end of $1980 ; 1985$ profits then fall almost continuously through the summer of 1984 . There was no increase in 1985 profits to correspond to the dramatic stock price increase after mid-1982.

What should we conclude about the brave-new-world view? In the end, I find the two-stage mainstream argument more persuasive, although there remain genuine puzzles in the movement of the stock market and the dollar.

Alas, no brave new world have we, Nay, 'tis the drab old globe we see. The gallant Fed drives real rates high As structural deficits loom close by.

\section{General Discussion}

There were several objections to the reliance by Blanchard and Summers on the "vigorous" stock market as evidence that enhanced profitability was responsible for high interest rates. Robert Shiller pointed out that the increase in the stock market since 1982 is no more than a small wiggle in historical perspective, and cannot yet be differentiated from random disturbances. Joseph Pechman considered the choice of time period for evaluating stock performance arbitrary, and 
noted that the recovery of stocks after mid-1982 can be directly attributed to the easing of monetary policy without the need to appeal to a change in perceptions about profitability. He added that the relation of stock prices and bond returns is too weak to establish priors about whether current stock prices are unexpectedly strong.

Benjamin Friedman emphasized that the authors' analysis of stock prices relative to bond returns is appropriate only if bonds and equities are close substitutes. The empirical evidence on this issue shows just the opposite, suggesting that an increase in the supply of government bonds will raise the rate of return on bonds and lower the rate of return on equities. The higher bond rates are necessary to induce agents to hold more bonds, and the rates of return to equities are driven down as agents diversify out of their bond-laden portfolios.

Stanley Fischer argued that the degree of international financial market integration assumed by the paper is unrealistic, and that there is no evidence to support the position that the interest rate effects of a U.S. deficit are offset one-for-one by a French surplus. In the same vein, Friedman noted that U.S. and European financial assets are not very close substitutes. For one thing, exchange risk cannot be avoided because the forward exchange rate market cannot be used to cover longterm positions. Furthermore, the covariation of the rates of return of U.S. and European assets has historically been low.

Jeffrey Sachs challenged the authors' contention that higher real interest rates are a worldwide phenomenon. Current real rates in much of Europe are not higher than their average historical levels of the 1960s. Current real rates in Japan are due more to deregulation, which eliminated the extensive interest rate ceilings that had prevailed, than to any perceived increase in profitability. The Japanese experience suggests that financial deregulation in the United States may have played an important role in current high U.S. rates as well. Given that U.S. real interest rates and deficits are both well above historical levels, and that European interest rates and deficits are not, he found it reasonable to conclude that U.S. budget deficits are influencing U.S. interest rate levels. Sachs also noted that Summers, in a paper which looked at one hundred years of data, found that real rates are typically high in the immediate aftermath of a decline in the inflation rate. He reasoned that this fact should have been exploited in the authors' search for an explanation of present U.S. rates. 